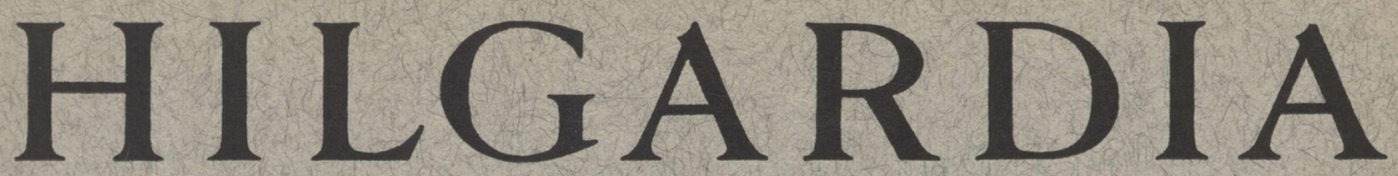

A Journal of Agricultural Science Publisbed by the California Agricultural Experiment Station

\title{
RESPONSE OF SEVERAL CROP PLANTS AND WEEDS TO MALEIC HYDRAZIDE
}

A. S. CRAFTS, H. B. CURRIER, and B. E. DAY 


\section{The results in brief ...}

Maleic hydrazide has been found to have selective herbicidal action on weedy grasses. Young plants are more susceptible to injury by it than are old plants. This relation of maturity to injury applies to crop plants as well as to weedy grasses.

Maleic hydrazide is particularly toxic to grass species. It affects plants when applied at low concentration; it causes growth abnormalities; it apparently acts on plant meristems at a distance from the point of application. For these reasons, it is concluded that maleic hydrazide has hormone properties.

Addition of a wetting agent increases the effects of maleic hydrazide, presumably by improving the contact with the plant tissues.

Many vegetable crops show growth inhibition from maleic hydrazide treatment; growth abnormalities occur on some. On tomato, the abnormalities resemble virus symptoms.

A common response to maleic hydrazide is anthocyanin pigmentation. This might result from carbohydrate accumulation in the leaves. 


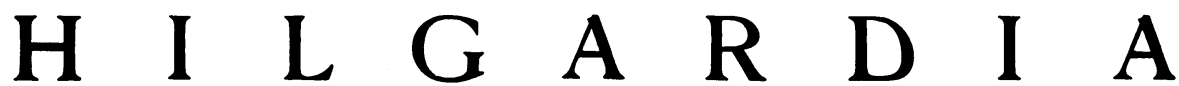

A Journal of Agricultural Science Published by

the California Agricultural Experiment Station

VOL. 20

JULY, 1950

No. 4

\section{RESPONSE OF \\ SEVERAL CROP PLANTS AND WEEDS \\ TO MALEIC HYDRAZIDE ${ }^{1}$}

\author{
A. S. Crafts, ${ }^{2}$ H. B. Currier, \\ and B. E. Day
}

WEEDY SPECIES of annual and perennial grasses present one of the most serious problems in weed control. Western climatic conditions limit the use of the two most promising grass killers so far developed.

Isopropyl-N-phenyl carbamate (IPC), a selective grass killer, is absorbed through the roots of plants. For this reason it must be mixed with, or leached into, the soil. This feature presents difficulties in the West, where rainfall may not occur after a crop is planted. Furthermore, IPC seems most potent against winter annual weeds. It has not proved satisfactory on western summer annual or perennial grasses.

Though trichloroacetic acid (TCA) salts are more effective than IPC against perennial grasses, relatively large quantities-100 to 200 pounds per acreare required. At lower dosages - 5 to 10 pounds per acre-the salts may control small annual grass seedlings but lack selectivity and, under many conditions, may injure crop plants.

Maleic hydrazide has been reported to have growth-regulating (Hoffmann and Schoene, 1949 ; Schoene and Hoffmann, 1949) ${ }^{5}$ as well as selective herbicidal (Currier and Crafts, 1950) properties. Preliminary tests have shown it particularly toxic to young grasses-plants against which 2,4-D is least effective. Should it prove as highly toxic and as widely selective as these tests indicate, maleic hydrazide may become an extremely useful material for controlling weedy grasses in field crops.

\footnotetext{
${ }^{1}$ Received for publication December 30, 1949.

2 Professor of Botany and Botanist in the Experiment Station.

${ }^{3}$ Assistant Professor of Botany and Assistant Botanist in the Experiment Station.

4 Junior Plant Pathologist, Citrus Experiment Station, Riverside, California.

5 See "Literature Cited" for data on citations referred to in the text by author and date.
} 


\section{PLANTS TESTED WITH MALEIC HYDRAZIDE}

The following plants were grown from seed in perforated number 10 cans :

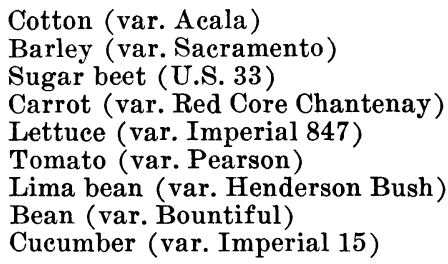

Crop Plants

\author{
Cantaloupe (var. unknown) \\ Watermelon (var. Klondike) \\ Squash (var. Yellow Crookneck) \\ Sweet corn (var. Country Gentleman) \\ Flax (var. Punjab) \\ Milo (var. Double Dwarf) \\ Sudangrass (common) \\ Rice (var. Calora)
}

\section{WEEDS}

Johnsongrass (Sorghum halepensis)

Watergrass (Echinochloa crus-galli)

General Methods of Applying the Solutions. A water soluble diethanolamine salt, containing 30 per cent maleic hydrazide ${ }^{8}$ by weight, was diluted to concentrations of $0.0,0.1,0.2,0.4$, and 0.8 per cent. The plants, on a slowly revolving platform, were sprayed from a fixed position with an atomizer (De Vilbiss, No. 261), oscillated by hand. Plants were sprayed at several stages of development and readings were taken on different dates. In most of the experiments the volume of spray solution was sufficient to wet the plants thoroughly. Vatsol at 0.024 per cent concentration was added as a spreader in many of the solutions.

The preliminary test-with barley about $20 \mathrm{~cm}$ high and the cotton plants approximately $30 \mathrm{~cm}$-has been reported by Currier and Crafts (1950).

Tests on Watergrass and Cotton. Young watergrass plants were transplanted from the field into young cotton cultures in the greenhouse. Other cultures of watergrass alone and of cotton alone were also established. When the cotton plants were 20 days old, ${ }^{7}$ with four true leaves expanded, and were $25 \mathrm{~cm}$ in height, all cultures were sprayed to runoff with maleic hydrazide at $0.1,0.2$, 0.4 , and 0.8 per cent concentrations. The watergrass plants were $15 \mathrm{~cm}$ high with five true leaves. Table 1 presents the results of this experiment. All cultures were duplicated; the values are averages of two. Figure 1 shows cultures sprayed with $0.1,0.2$, and 0.4 per cent concentrations.

Symptoms of Injury. When sprayed with 0.2 per cent concentration and above, the watergrass ceased growth immediately. The leaves turned red with anthocyanin pigmentation, matured, and died. At 0.1 per cent, though growth was retarded, tillering became profuse. The plants assumed a bunchy appearance with many small green shoots. At the date of the final reading, they were less than half as tall as the controls and had failed to mature.

As a result of the 0.8 and 0.4 per cent concentrations, cotton plants were retarded and had malformed leaves (fig. 2). Those receiving 0.1 and 0.2 per cent sprays grew and blossomed well; at the 0.2 per cent concentration, they became slightly stunted.

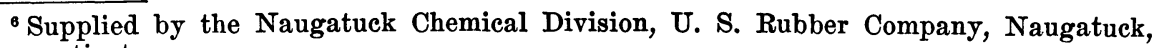
Connecticut.

${ }^{7}$ Twenty days from the time of seeding.
} 


\section{RELATION OF INJURY TO PLANT AGE}

Since 20-day-old cotton plants had been injured more severely than older ones, it seemed advisable to spray even younger plants. Ten-day-old cotton and sugar-beet plants in the advanced cotyledon stage and watergrass plants with 2 or 3 leaves were sprayed with maleic hydrazide solutions containing $0.012,0.024$, and 0.048 per cent Vatsol wetting agent (table 2).

Although the wetting agent increased the spreading quality of the sprays, it produced significant effects in only the final results of the grass cultures (fig. 3). The data reported on watergrass refer to cultures sprayed with solutions containing 0.024 per cent (fig. 4) and 0.048 per cent Vatsol. The values are averages of the two cultures, since plants treated with the two Vatsol concentrations showed little difference in response.

In the results obtained on cotton and sugar beets, each value represents an average of the three Vatsol treatments and the control series, or an average of four separate treatments. Figures 5 and 6 show the effects upon cotton and sugar beets, respectively, 51 days after treatment.

TABLE 1

PER CENT INJURY* TO WATERGRASS AND COTTON FROM MALEIC HYDRAZIDE SPRAYS

(Applied May 31, 1949)

\begin{tabular}{|c|c|c|c|c|c|c|c|c|}
\hline \multirow{3}{*}{$\begin{array}{c}\text { Concentration of spray, } \\
\text { per cent }\end{array}$} & \multicolumn{4}{|c|}{ Watergrass $\dagger$} & \multicolumn{4}{|c|}{ Cotton } \\
\hline & \multicolumn{2}{|c|}{ Alone } & \multicolumn{2}{|c|}{ In cotton } & \multicolumn{2}{|c|}{ Alone } & \multicolumn{2}{|c|}{ In watergrass } \\
\hline & June 28 & Sept. 23 & June 28 & Sept. 23 & June 28 & Sept. 23 & June 28 & Sept. 23 \\
\hline 0.0 & 0 & 0 & 0 & 0 & 0 & 0 & 0 & 0 \\
\hline $0.1 \ldots \ldots \ldots \ldots \ldots$ & 10 & 50 & 6 & 50 & 0 & 0 & 0 & 0 \\
\hline $0.2 \ldots \ldots \ldots \ldots \ldots \ldots \ldots$ & 40 & 100 & 27 & 75 & 10 & 20 & 12 & 15 \\
\hline $0.4 \ldots \ldots \ldots \ldots \ldots \ldots \ldots$ & 50 & 100 & 40 & 100 & 25 & 30 & 25 & 20 \\
\hline $0.8 \ldots \ldots \ldots \ldots \ldots \ldots \ldots$ & 50 & 100 & 47 & 100 & 35 & 40 & 30 & 30 \\
\hline
\end{tabular}

* Controls used as standard for comparison.

† Differences in injury to watergrass here may result from shielding of the grass by the cotton plants.

TABLE 2

PER CENT INJURY* TO 10-DAY-OLD WATERGRASS, COTTON, AND SUGAR BEETS FROM MALEIC HYDRAZIDE SPRAYS

(Applied June 28, 1949)

\begin{tabular}{|c|c|c|c|c|c|c|c|c|c|}
\hline \multirow{2}{*}{$\begin{array}{l}\text { Concentration } \\
\text { of spray, } \\
\text { per cent }\end{array}$} & \multicolumn{3}{|c|}{ Watergrass } & \multicolumn{3}{|c|}{ Cotton } & \multicolumn{3}{|c|}{ Sugar Beet } \\
\hline & Aug. 1 & Aug. 18 & Sept. 23 & Aug. 1 & Aug. 18 & Sept. 23 & Aug. 1 & Aug. 18 & Sept. 23 \\
\hline 0.0. & 0 & 0 & 0 & 0 & 0 & 0 & 0 & 0 & 0 \\
\hline $0.1 \ldots \ldots \ldots \ldots$ & 25 & 50 & 60 & 64 & 65 & 70 & 45 & 54 & 60 \\
\hline $0.2 \ldots \ldots \ldots$ & 90 & 98 & 100 & 78 & 84 & 85 & 69 & 79 & 80 \\
\hline $0.4 \ldots \ldots \ldots$ & 92 & 100 & 100 & 84 & 90 & 95 & 85 & 95 & 99 \\
\hline $0.8 \ldots \ldots \ldots \ldots$ & 95 & 100 & 100 & 86 & 95 & 99 & 93 & 100 & 100 \\
\hline
\end{tabular}

* Controls used as standard for comparison. 


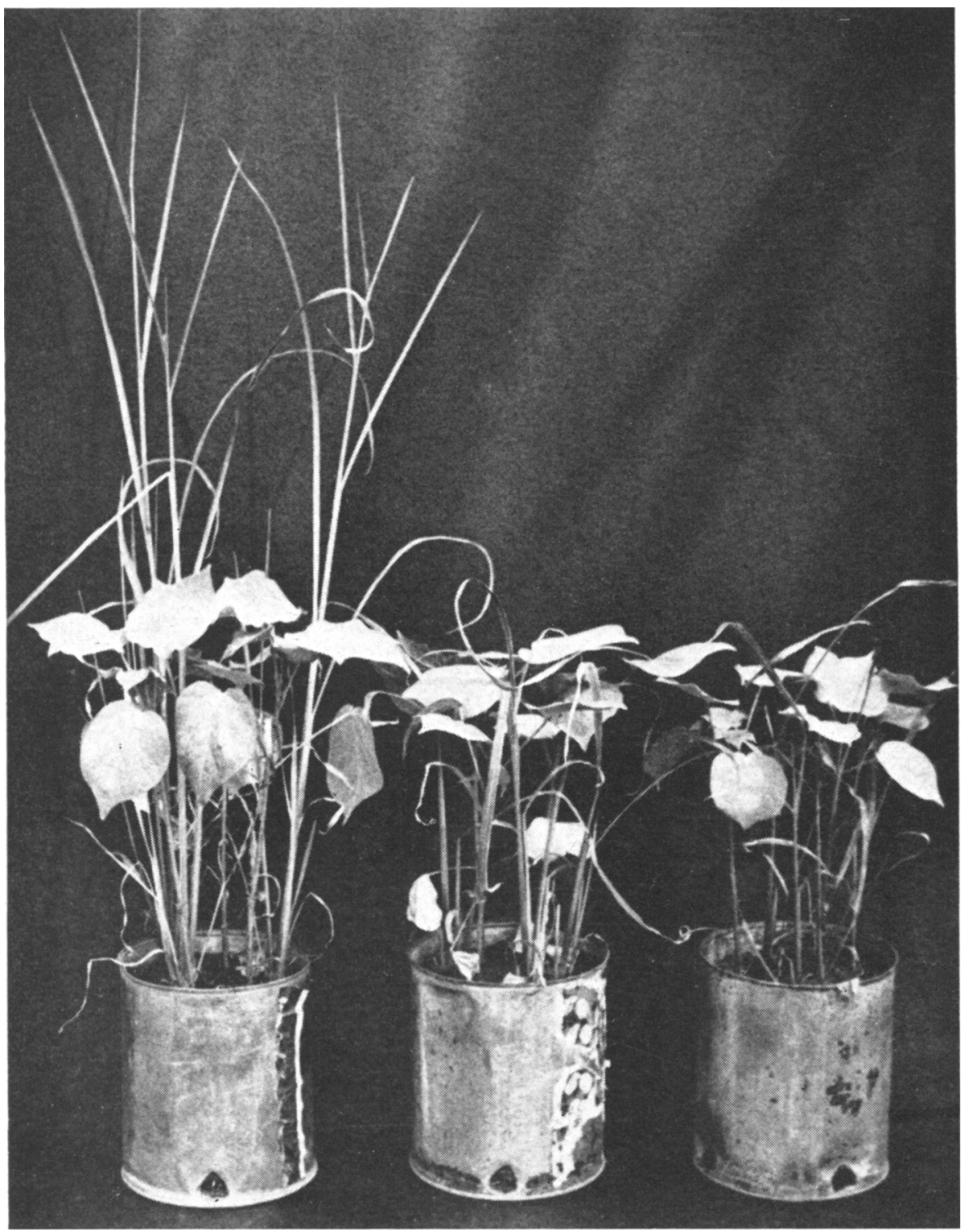

Fig. 1. Cotton and watergrass. Left to right: $0.1,0.2$, and 0.4 per cent maleic hydrazide, without wetting agent. Photographed 5 weeks after spraying. 


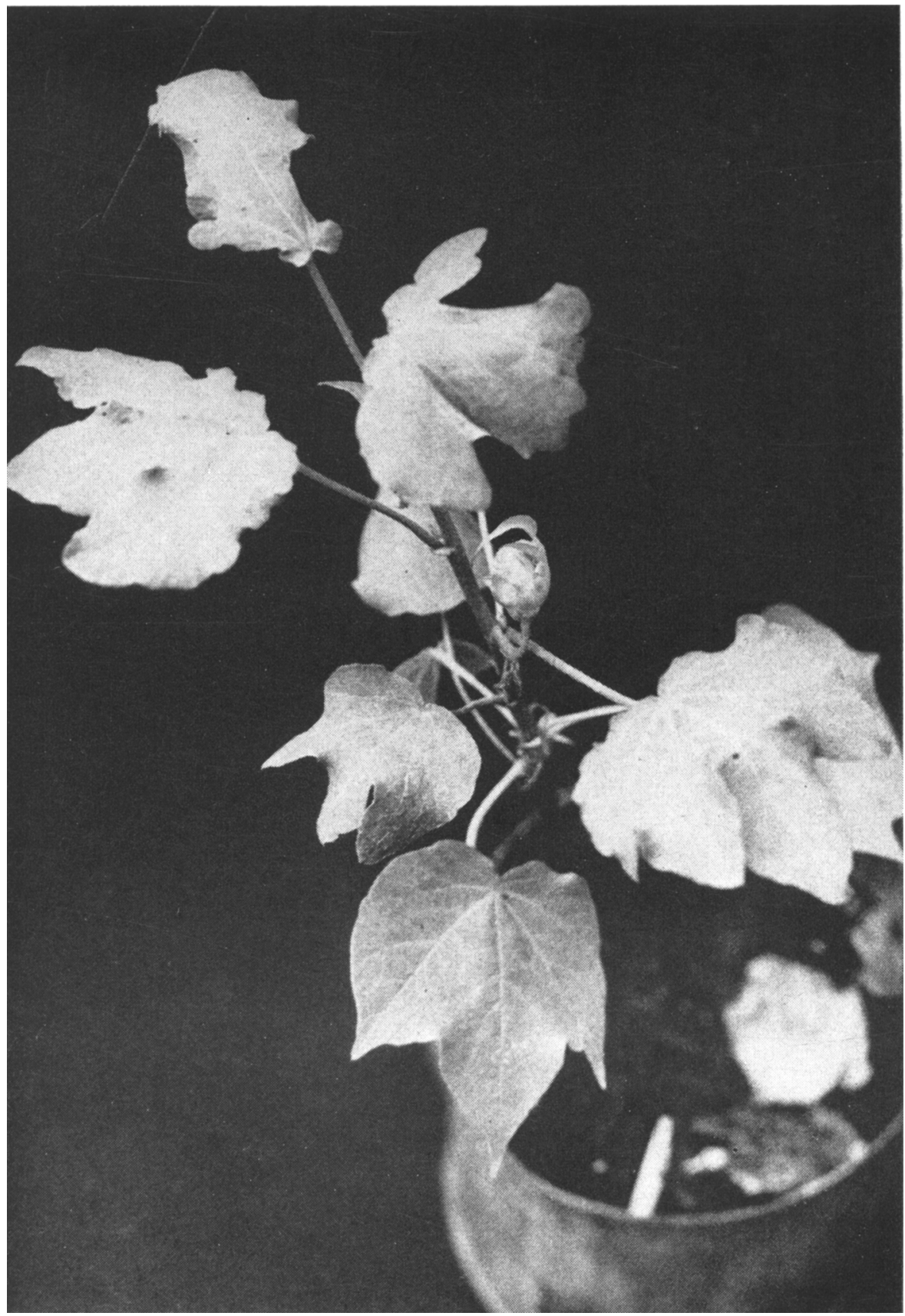

Fig. 2. Typical malformation of cotton leaves induced by high concentration ( 0.8 per cent) of maleic hydrazide. 


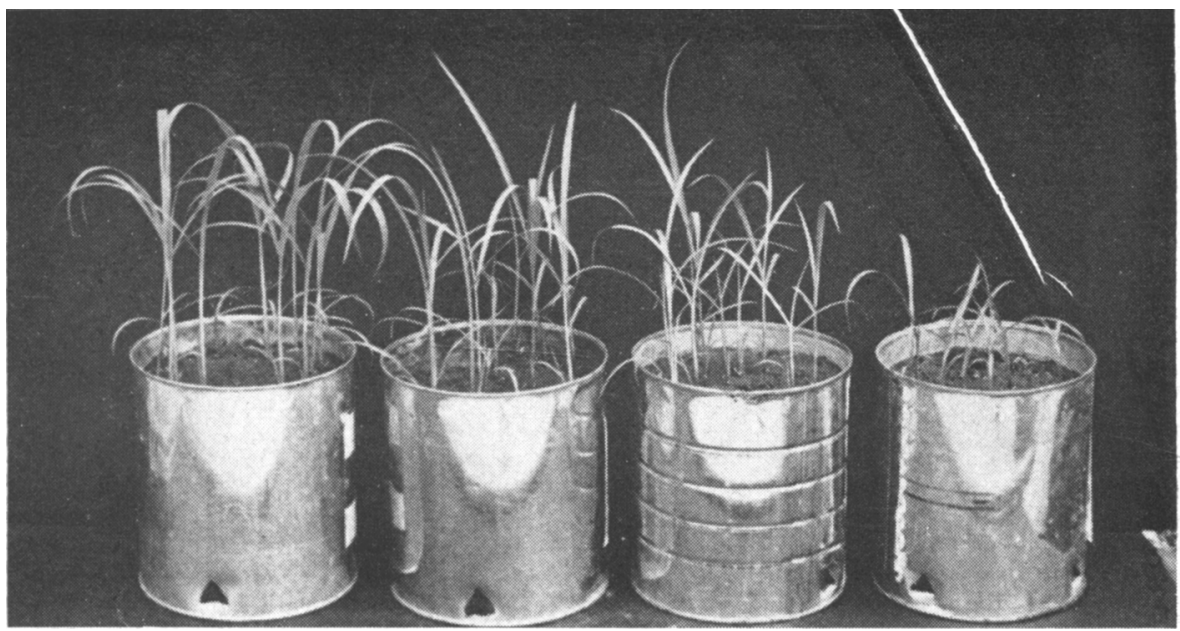

Fig. 3. Watergrass sprayed with maleic hydrazide. Left to right: control, 0.1 per cent with no Vatsol, 0.1 per cent with 0.012 per cent Vatsol, 0.1 per cent with 0.024 per cent Vatsol. Photographed 9 days after treatment.

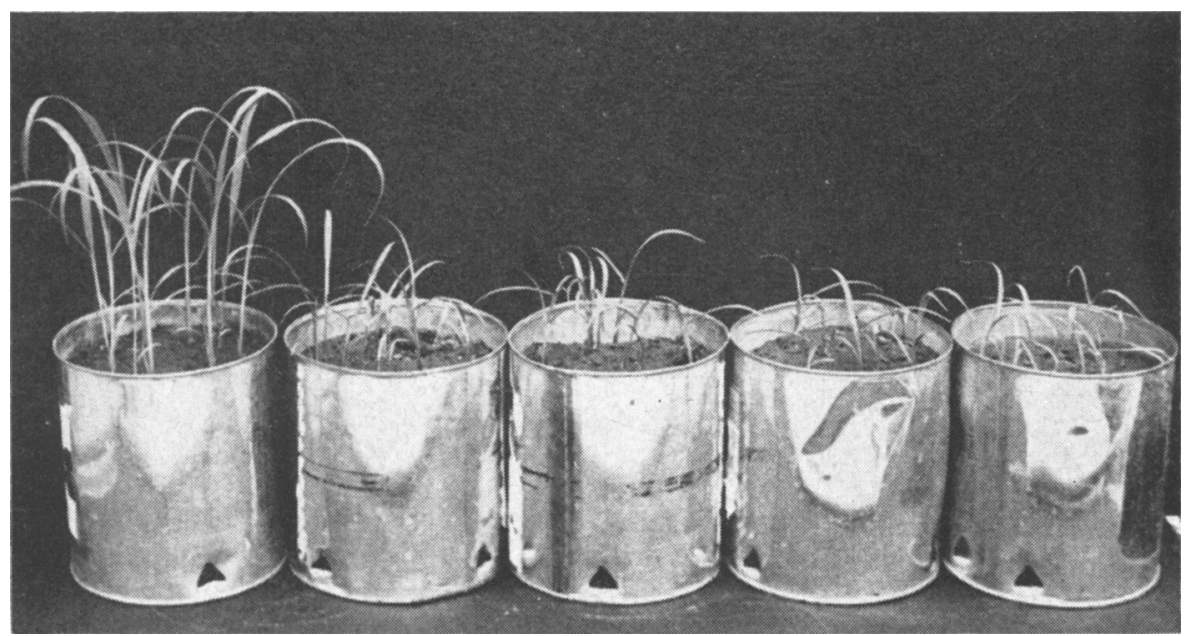

Fig. 4. Watergrass sprayed with maleic hydrazide. Left to right: control, 0.1, 0.2, 0.4, and 0.8 per cent; Vatsol, 0.024 per cent. Photographed 9 days after treatment. 


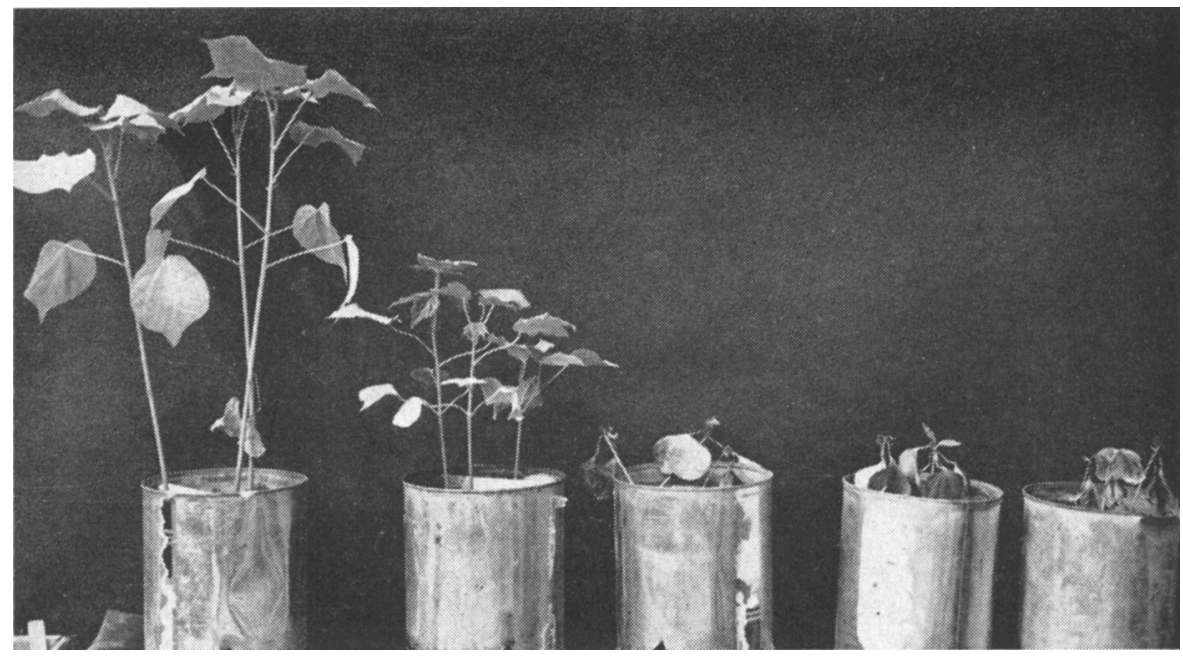

Fig. 5. Cotton sprayed when 10 days old with maleic hydrazide. Left to right: control, $0.1,0.2,0.4$, and 0.8 per cent; Vatsol, 0.024 per cent. Photographed 51 days after treatment.

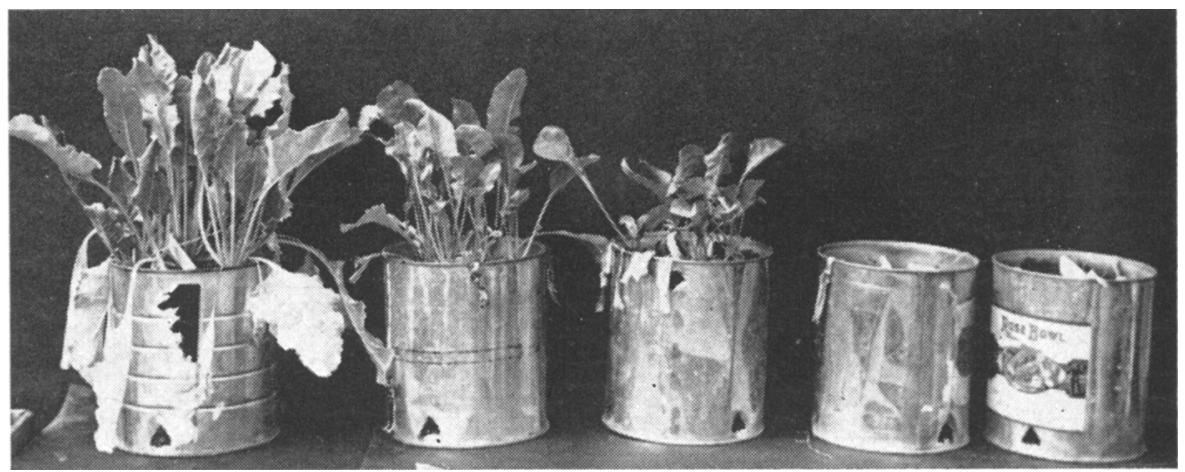

Fig. 6. Sugar beets sprayed when 10 days old with maleic hydrazide. Left to right: control, $0.1,0.2,0.4$, and 0.8 per cent; Vatsol, 0.024 per cent. Photographed 51 days after treatment. 
These tests indicated that the age of the plants at the time of treatment was a primary factor in determining the extent of injury. Young plants were much more susceptible to growth inhibition and tissue destruction than were old ones. Furthermore, different species varied in response. Thorough testing is necessary, therefore, before maleic hydrazide can be used in the field, particularly as a selective killer of weedy grasses.

As a further test, 29-day-old cotton, sugar-beet, and watergrass plants were sprayed with $0.1,0.2$, and 0.4 concentrations of maleic hydrazide, each contain-

TABLE 3

INHIBITION OF GROWTH* OF 29-DAY-OLD WATERGRASS, COTTON, AND SUGAR BEETS FROM MALEIC HYDRAZIDE SPRAYS

(Applied July 26, 1949)

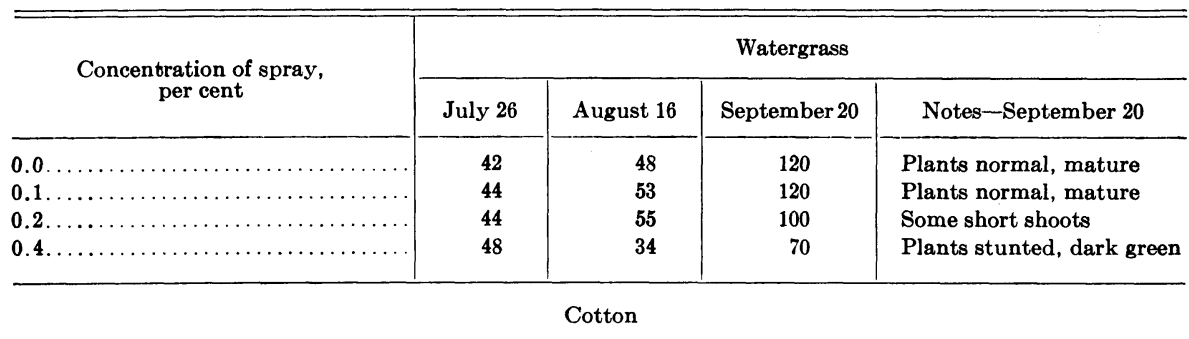

\begin{tabular}{|c|c|c|c|c|}
\hline 0.0 . & 33 & 45 & 66 & Plants normal with buds \\
\hline 0.2 . & 32 & 38 & 60 & Bunchy growth at top \\
\hline
\end{tabular}

Sugar Beet

\begin{tabular}{|c|c|c|c|c|}
\hline 0.0 . & 20 & 25 & 30 & Plants normal, growing \\
\hline $0.1 \ldots \ldots \ldots$ & 20 & 24 & 35 & Slightly abnormal leaves \\
\hline $0.2 \ldots \ldots$ & 20 & 23 & 35 & Leaves narrow and stunted \\
\hline 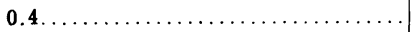 & 20 & 23 & 28 & Leaves narrow and stunted \\
\hline
\end{tabular}

* Inhibition as expressed by plant height in centimeters.

ing 0.024 per cent Vatsol. Because these older plants suffered very little actual injury but were simply inhibited in growth, data are given in terms of plant height (table 3 ).

Injury to these older plants was much less prominent than that to the 10 day-old ones. Cotton and sugar-beet leaves that were expanded at the time of treatment showed no change in form or size; those of watergrass turned a dull red color and ceased growth. Inhibition and abnormal growth were confined to the plant tips of cotton (fig. 7) and of sugar beets (fig. 8). Details of leaf injury to sugar-beet plants are pictured in figure 9 .

Effects of spraying the several plant parts were also observed during this experiment. The younger cotton plants receiving spray on only the cotyledons and stems were markedly stunted and developed abnormal leaves at the tips. Those sprayed on the first and second leaves, as well as on stems and cotyledons, showed the same type of injury, though in less degree. 


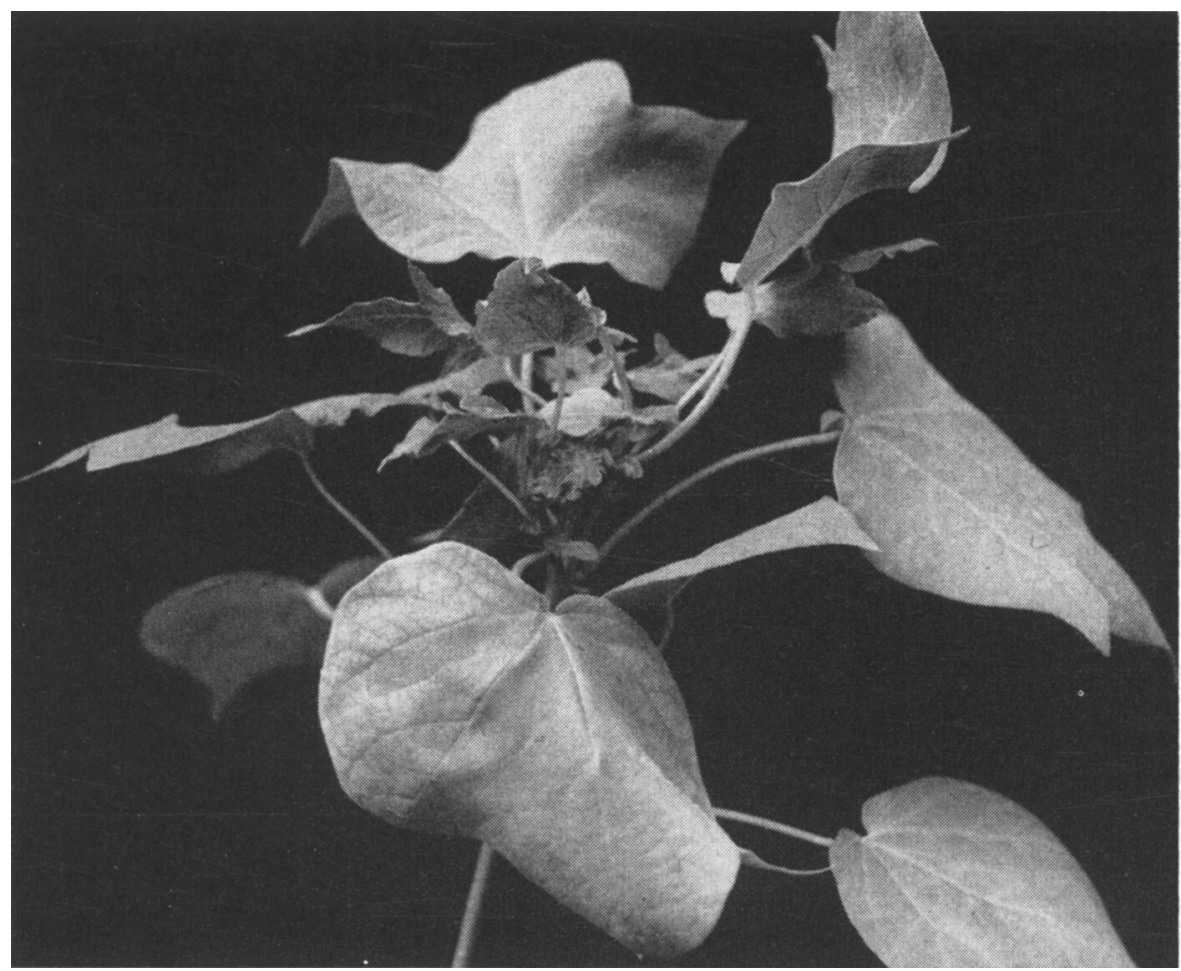

Fig. 7. Growth response of cotton sprayed when 29 days old with 0.4 per cent maleic hydrazide and 0.024 per cent Vatsol. Photographed 60 days after treatment.

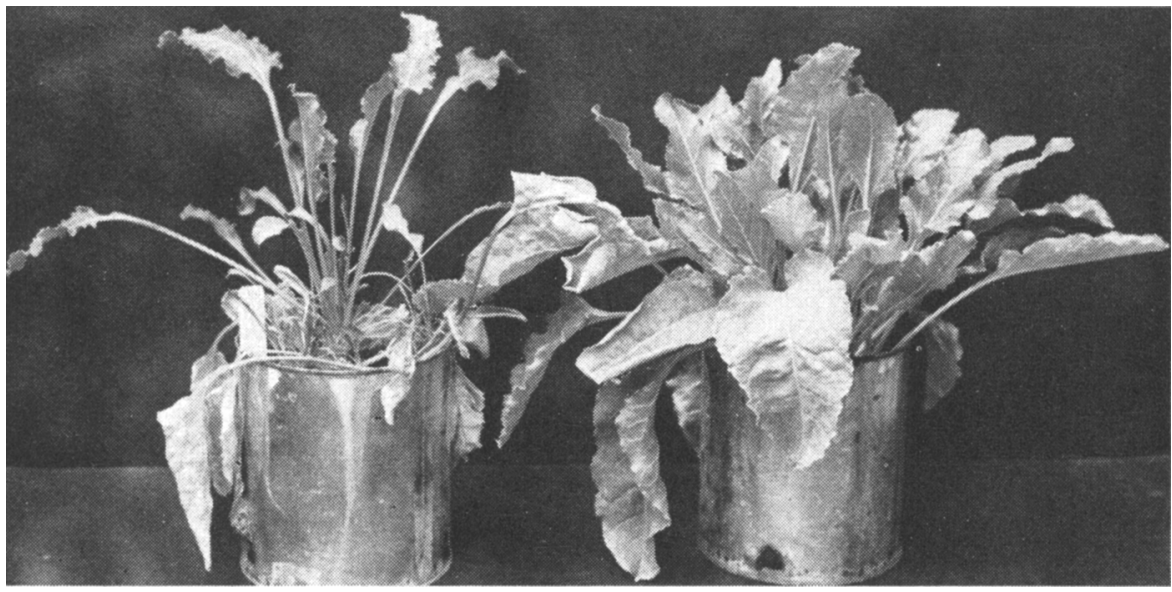

Fig. 8. Growth response of sugar beets sprayed with 0.2 per cent maleic hydrazide and 0.024 per cent Vatsol. Left: treated when 29 days old. Right: control. Photographed 8 weeks later. 
[Vol. 20, No. 4

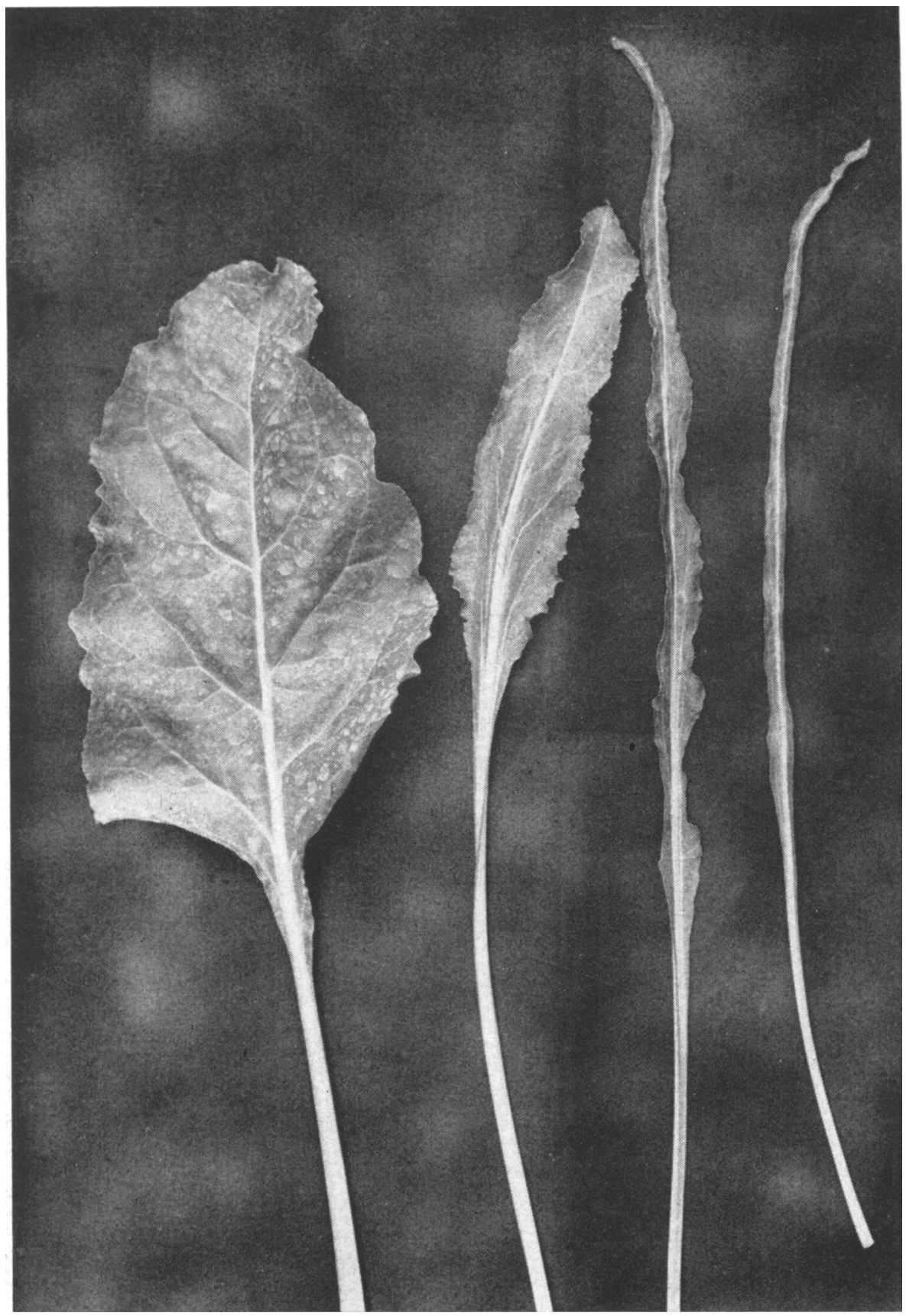

Fig. 9. Types of malformed leaves of sugar beets treated with maleic hydrazide. Leaf on the left is essentially normal. 
Also included in the experiment were watergrass cultures, which were divided into four groups. These received the 0.1 per cent maleic hydrazide solution in 1, 2, 3, or 4 applications at weekly intervals. An additional group received two sprays with the 0.2 per cent solution, these being spaced one week apart. Because of the lag in application time, inhibition of all these plants was somewhat less than that shown by plants receiving the total amount of chemical ( 0.4 per cent) in one application. After 34 days, however, the plants having repeated sprays developed symptoms as severe as on those given an equal

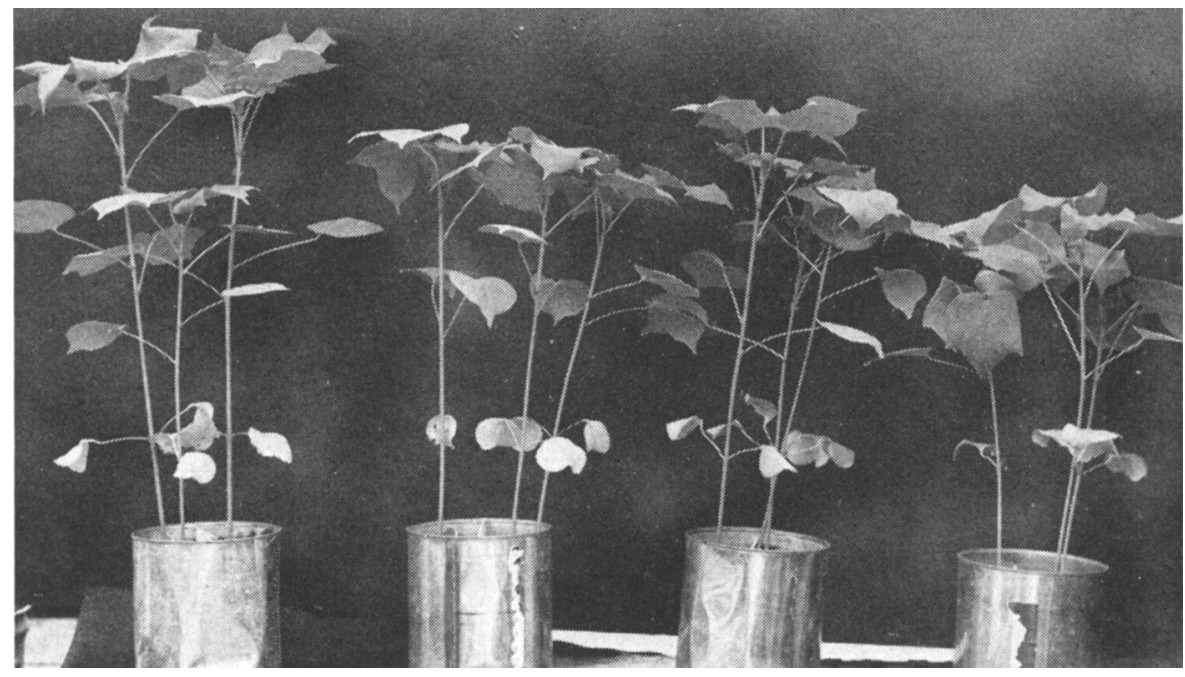

Fig. 10. Cotton sprayed when 44 days old with maleic hydrazide. Left to right: control, $0.1,0.2$, and 0.4 per cent; Vatsol, 0.024 per cent. Photographed 46 days after treatment.

dose as a single application. The results indicate that applications are additive and that the breakdown of the chemical-once it has been absorbed-is slow.

To check still further on the relation of age to maleic hydrazide response, 44-day-old cotton plants were sprayed with the same series of concentrations used on 29-day-old plants. Examined 44 days later, these plants showed little change. Those receiving 0.4 per cent spray were slightly inhibited but evidenced no malformation of leaves and only slight retardation of bud formation. Figure 10 shows one replicate of this test. These results confirm the findings described in the preliminary report (Currier and Crafts, 1950) for older cotton plants. They also indicate that young grass in mature cotton may be sprayed without injury to the crop.

In marked contrast was the type of response shown by 10-day-old cotton plants receiving 0.2 per cent maleic hydrazide spray. The main shoot in these plants was completely inhibited slightly above the cotyledonary node. After some time the axillary buds of this node developed into twin shoots (fig. 11a). The main shoot and other buds were not killed but were simply retarded in their development (fig. 11b). 
Response of Common Field and Vegetable Crops. When sugar beets, 44 days old, were sprayed with maleic hydrazide at concentrations of $0.0,0.1,0.2$, and 0.4 per cent, all new growth was stunted to some degree. Modifications were of the types illustrated in figures 8 and 9.

To observe types of response in common field and vegetable crops to maleic hydrazide, 13 crop species, all 20 days old, were sprayed with the same series

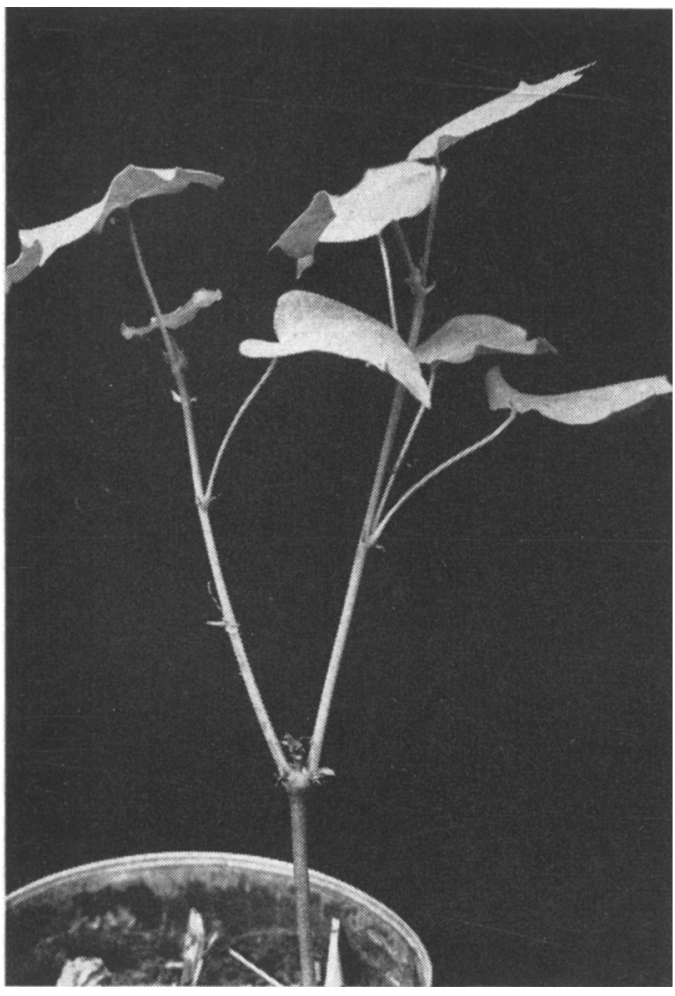

$a$

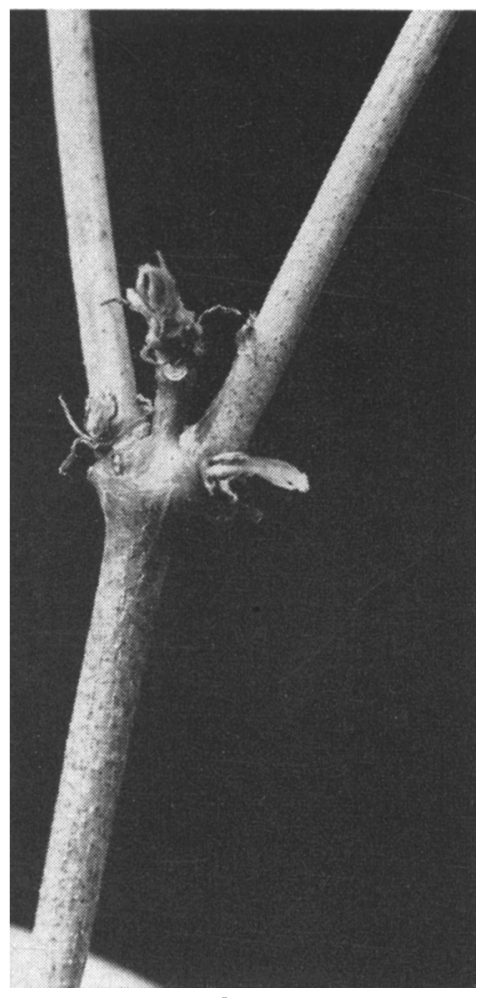

$b$

Fig. 11. Cotton sprayed when 10 days old with 0.2 per cent maleic hydrazide and 0.048 per cent Vatsol. a) The terminal bud was inhibited and shoots developed from both buds at the cotyledonary node. $b$ ) Close-up of cotyledonary node. Photographed 89 days after treatment.

of concentrations containing 0.024 per cent Vatsol. Watergrass and Johnsongrass were included as representatives of weedy grasses. Table 4 presents the results in terms of plant height, with notes on abnormalities. Figures 12 to 25 illustrate the types of response observed.

From these data and the photographs, it is evident that responses from applications of maleic hydrazide sprays were variable. On carrots, stunting of the young leaves was most prominent. Lettuce was stunted and chlorotic at 0.2 and 0.4 per cent concentrations; 0.1 per cent induced early bolting.

At the 0.4 concentration young tomato plants showed symptoms reminiscent of curly-top virus (fig. 13) ; stunting was prominent. Plants receiving 0.1 per 


\section{TABLE 4}

EFFECTS OF MALEIC HYDRAZIDE SPRAYED ON 20-DAY-OLD CROP PLANTS AND WEEDS

(Applied July 26, 1949)

\begin{tabular}{|c|c|c|c|c|c|}
\hline \multirow{2}{*}{ Crop plant } & \multirow{2}{*}{$\begin{array}{l}\text { Concen- } \\
\text { tration } \\
\text { of spray, } \\
\text { per cent }\end{array}$} & \multicolumn{3}{|c|}{ Height, cm } & \multirow{2}{*}{ Notes-September 20} \\
\hline & & July 26 & August 12 & Sept. 20 & \\
\hline Carrot & $\begin{array}{l}0.0 \\
0.1 \\
0.2 \\
0.4\end{array}$ & $\begin{array}{r}9 \\
9 \\
9 \\
10\end{array}$ & $\begin{array}{l}18 \\
18 \\
16 \\
14\end{array}$ & $\begin{array}{l}32 \\
38 \\
35 \\
16\end{array}$ & $\begin{array}{l}\text { Normal } \\
\text { Slight stunting } \\
\text { Stunting at crown } \\
\text { Stunted and swollen at crown }\end{array}$ \\
\hline Lettuce & $\begin{array}{l}0.0 \\
0.1 \\
0.2 \\
0.4\end{array}$ & $\begin{array}{l}9 \\
8 \\
8 \\
8\end{array}$ & $\begin{array}{r}14 \\
10 \\
13 \\
8\end{array}$ & $\begin{array}{l}20 \\
90 \\
25 \\
10\end{array}$ & $\begin{array}{l}\text { Starting to bolt } \\
\text { Severely bolted } \\
\text { Bunchy stunting, bolted } \\
\text { Plants chlorotic and dying }\end{array}$ \\
\hline Tomato & $\begin{array}{l}0.0 \\
0.1 \\
0.2 \\
0.4\end{array}$ & $\begin{array}{l}10 \\
10 \\
10 \\
10\end{array}$ & $\begin{array}{l}23 \\
20 \\
16 \\
10\end{array}$ & $\begin{array}{l}60 \\
45 \\
24 \\
12\end{array}$ & $\begin{array}{l}\text { Plants normal } \\
\text { Stunted, slender growth } \\
\text { Bunchy stunting } \\
\text { No growth, plants dying }\end{array}$ \\
\hline Lima Bean & $\begin{array}{l}0.0 \\
0.1 \\
0.2 \\
0.4\end{array}$ & $\begin{array}{l}19 \\
18 \\
16 \\
17\end{array}$ & $\begin{array}{l}50 \\
30 \\
19 \\
19\end{array}$ & $\begin{array}{l}60 \\
33 \\
28 \\
25\end{array}$ & $\begin{array}{l}\text { Plants mature, fruits drying } \\
\text { Stunting and some blossoms } \\
\text { Bunchy, blossoms, no fruits } \\
\text { Stunted, green, just blossoming }\end{array}$ \\
\hline Bean & $\begin{array}{l}0.0 \\
0.1 \\
0.2 \\
0.4\end{array}$ & $\begin{array}{l}33 \\
36 \\
34 \\
33\end{array}$ & $\begin{array}{l}75 \\
50 \\
41 \\
42\end{array}$ & $\begin{array}{l}90 \\
45 \\
35 \\
35\end{array}$ & $\begin{array}{l}\text { Plants mature, fruits dry } \\
\text { Stunted, flowers and fruit } \\
\text { Stunted, no flowers or fruits } \\
\text { Plants dead }\end{array}$ \\
\hline Cucumber & $\begin{array}{l}0.0 \\
0.1 \\
0.2 \\
0.4\end{array}$ & $\begin{array}{l}16 \\
17 \\
17 \\
16\end{array}$ & $\begin{array}{l}63 \\
36 \\
26 \\
16\end{array}$ & $\begin{array}{r}170 \\
110 \\
50 \\
25\end{array}$ & $\begin{array}{l}\text { Normal, flowers, fruits } \\
\text { Stunted, fruits } \\
\text { Stunted, odd-shaped fruits } \\
\text { Badly stunted }\end{array}$ \\
\hline Cantaloupe & $\begin{array}{l}0.0 \\
0.1 \\
0.2 \\
0.4\end{array}$ & $\begin{array}{l}6 \\
6 \\
6 \\
5\end{array}$ & $\begin{array}{r}34 \\
14 \\
9 \\
7\end{array}$ & $\begin{array}{r}180 \\
50 \\
12 \\
8\end{array}$ & $\begin{array}{l}\text { Normal, flowers and small truits } \\
\text { Plants stunted, flowers and fruits } \\
\text { Plants dead } \\
\text { Plants dead }\end{array}$ \\
\hline Watermelon & $\begin{array}{l}0.0 \\
0.1 \\
0.2 \\
0.4\end{array}$ & $\begin{array}{l}8 \\
8 \\
8 \\
8\end{array}$ & $\begin{array}{l}20 \\
18 \\
16 \\
13\end{array}$ & $\begin{array}{r}70 \\
90 \\
100 \\
70\end{array}$ & $\begin{array}{l}\text { Plants normal, flowers and young fruits } \\
\text { Plants normal, flowers and young fruits } \\
\text { Plants normal, flowers and young fruits } \\
\text { Plants stunted, flowers and young fruits }\end{array}$ \\
\hline Squash & $\begin{array}{l}0.0 \\
0.1 \\
0.2 \\
0.4\end{array}$ & $\begin{array}{l}16 \\
16 \\
16 \\
16\end{array}$ & $\begin{array}{l}29 \\
23 \\
20 \\
16\end{array}$ & $\begin{array}{l}45 \\
40 \\
35 \\
25\end{array}$ & $\begin{array}{l}\text { Plants normal, flowers and young fruits } \\
\text { Plants normal, flowers and young fruits } \\
\text { Plants stunted, flowers and young fruits } \\
\text { Bunchy stunting, flowers and young fruits }\end{array}$ \\
\hline Sweet Corn & $\begin{array}{l}0.0 \\
0.1 \\
0.2 \\
0.4\end{array}$ & $\begin{array}{l}21 \\
24 \\
26 \\
26\end{array}$ & $\begin{array}{l}44 \\
48 \\
51 \\
33\end{array}$ & $\begin{array}{r}120 \\
140 \\
120 \\
35\end{array}$ & $\begin{array}{l}\text { Plants normal with tassels } \\
\text { Plants normal with tassels } \\
\text { Plants normal with tassels } \\
\text { Plants injured and dying }\end{array}$ \\
\hline Flax & $\begin{array}{l}0.0 \\
0.1 \\
0.2 \\
0.4\end{array}$ & $\begin{array}{l}14 \\
14 \\
14 \\
14\end{array}$ & $\begin{array}{l}28 \\
16 \\
15 \\
14\end{array}$ & $\begin{array}{l}50 \\
18 \\
16 \\
15\end{array}$ & $\begin{array}{l}\text { Plants normal, blossoming } \\
\text { Plants stunted, no flowers } \\
\text { Plants badly stunted } \\
\text { Plants badly stunted }\end{array}$ \\
\hline
\end{tabular}


TABLE 4-Concluded

\begin{tabular}{|c|c|c|c|c|c|}
\hline \multirow{2}{*}{ Crop plant } & \multirow{2}{*}{$\begin{array}{l}\text { Concen- } \\
\text { tration } \\
\text { of spray, } \\
\text { per cent }\end{array}$} & \multicolumn{3}{|c|}{ Height, cm } & \multirow{2}{*}{ Notes-September 20} \\
\hline & & July 26 & August 12 & Sept. 20 & \\
\hline Milo & $\begin{array}{l}0.0 \\
0.1 \\
0.2 \\
0.4\end{array}$ & $\begin{array}{l}31 \\
32 \\
31 \\
31\end{array}$ & $\begin{array}{l}30 \\
21 \\
29 \\
26\end{array}$ & $\begin{array}{l}40 \\
36 \\
30 \\
29\end{array}$ & $\begin{array}{l}\text { Plants normal, heads forming } \\
\text { Plants stunted with tillering } \\
\text { Plants dead } \\
\text { Plants dead }\end{array}$ \\
\hline Sudangrass & $\begin{array}{l}0.0 \\
0.1 \\
0.2 \\
0.4\end{array}$ & $\begin{array}{l}21 \\
21 \\
22 \\
24\end{array}$ & $\begin{array}{l}70 \\
24 \\
22 \\
24\end{array}$ & $\begin{array}{l}80 \\
25 \\
25 \\
20\end{array}$ & $\begin{array}{l}\text { Plants normal, heads forming } \\
\text { Plants stunted } \\
\text { Plants badly stunted } \\
\text { Plants dying }\end{array}$ \\
\hline Rice & $\begin{array}{l}0.0 \\
0.1 \\
0.2 \\
0.4\end{array}$ & $\begin{array}{l}7 \\
9 \\
8 \\
8\end{array}$ & $\begin{array}{r}20 \\
10 \\
8 \\
8\end{array}$ & $\begin{array}{l}35 \\
15 \\
10 \\
10\end{array}$ & $\begin{array}{l}\text { Plants normal } \\
\text { Plants stunted, dead } \\
\text { Plants stunted, dead } \\
\text { Plants stunted, dead }\end{array}$ \\
\hline Johnsongrass & $\begin{array}{l}0.0 \\
0.1 \\
0.2 \\
0.4\end{array}$ & $\begin{array}{r}10 \\
9 \\
10 \\
11\end{array}$ & $\begin{array}{l}60 \\
35 \\
10 \\
10\end{array}$ & $\begin{array}{r}100 \\
35 \\
10 \\
10\end{array}$ & $\begin{array}{l}\text { Plants normal, heading } \\
\text { Plants stunted, lower leaves dead } \\
\text { Plants stunted, dead } \\
\text { Plants stunted, dead }\end{array}$ \\
\hline Watergrass & $\begin{array}{l}0.0 \\
0.1 \\
0.2 \\
0.4\end{array}$ & $\begin{array}{l}22 \\
23 \\
22 \\
22\end{array}$ & $\begin{array}{l}80 \\
50 \\
20 \\
15\end{array}$ & $\begin{array}{r}100 \\
70 \\
20 \\
20\end{array}$ & $\begin{array}{l}\text { Plants normal, mature, headed } \\
\text { Plants somewhat stunted } \\
\text { Plants stunted, dead } \\
\text { Plants badly stunted, dead }\end{array}$ \\
\hline
\end{tabular}

cent spray had odd-shaped leaves, like those resulting from shoe-string virus. Symptoms resembling those of virus infection have also been noted by Kunkel (1943) and Zimmerman (1943), working with other growth regulators.

The beans, squash, and cucumbers were stunted but were not otherwise particularly abnormal. Watermelon showed the greatest tolerance of any species studied; flax was severely stunted. All grass species were stunted, and many were killed by the two higher concentrations. Where comparisons could be made, the 20-day-old plants were less affected than those 10 days old.

Effect of Maturity in Field and Vegetable Crops. To check further on the relation of maturity to effects from maleic hydrazide, 35-day-old plants of most of the species reported in table 4 were treated. These trials proved again that the more mature plants were less severely affected. Stunting was the principal symptom. As before, the stunted plants matured more slowly than normal controls. Grass plants were most seriously injured by the sprays.

In a separate test on Johnsongrass in various stages of development, plants up to $50 \mathrm{~cm}$ in height were completely inhibited and eventually killed. The plants shown on the right in figure 25 had been sprayed about three weeks previously with 0.2 per cent maleic hydrazide containing 0.024 per cent Vatsol. The plants ceased growth almost immediately; the leaves turned red, then brown; and at the time the plants were photographed, the tops were practically dead. 


\section{DISCUSSION}

These trials indicate that maleic hydrazide is a hormone-like growth regulator. At relatively high concentrations - 0.4 per cent and above-the principal reaction seems to be growth inhibition. This response is particularly striking in grasses and may eventually result in the death of the plants.

Many abnormalities appear at somewhat lower concentrations although growth may continue. The misshapen leaves of cotton (fig. 2), sugar beet (fig. 9), and tomato (fig. 15) are examples. Even at these concentrations, inhibition of growth is pronounced. At concentrations of 0.1 per cent and below, abnormalities are less prominent and inhibition less evident.

Response of grass plants gives further proof of the hormonal properties of maleic hydrazide. Even when it was used without a spreader, so that little chemical adhered to the plants, its lethal action killed young grass seedlings. Apparently, the chemical is translocated from the leaves into the meristematic regions-the same type of action that makes $2,4-\mathrm{D}$ such a valuable herbicide for controlling many broad-leaved species. It is significant that this chemical alters the growth of plants, but it is equally significant that the alteration takes place at a distance from the point of application: Similar treatments with substituted phenols, arsenic, or other contact killers do not kill the plants, because these substances are not translocated. Whether maleic hydrazide moves deep into the underground roots of perennial grasses remains to be studied. Preliminary tests prove that, when picked up from the soil by the roots, it kills the grass tops.

Its tolerance by mature broad-leaved plants, as compared with young ones, is another important property of maleic hydrazide. If this chemical proves to be a good grass killer in the field, it may be useful for controlling grassy weeds in such crops as cotton, row-planted flax, alfalfa, and clover. It should also be valuable in many other vegetable and field crops in which grasses germinate and develop after the crop is up.

As a nonselective grass killer, maleic hydrazide gives much promise. At 0.2 per cent concentration, it has killed young plants of every grass species so far tested. It has completely inhibited growth of the perennial Johnsongrass throughout one season when the plants were treated at various stages up to 16 inches in height.

If maleic hydrazide is to be used as a growth inhibitor, attention should be given to the concentration used, the plant species involved, and the age and growth conditions of the plants being treated.

\section{ACKNOWLEDGMENT}

The authors appreciate the assistance given by Harold Drever, Senior Laboratory Technician, Division of Botany, Davis, for growing the greenhouse plants used in these studies. 


\section{LITERATURE CITED}

Currier, H. B., and A. S. Crafts.

1950. Maleic hydrazide, a selective herbicide. Science 111: 152-153.

HofrmanN, O. L., and D. L. Schoene.

1949. Maleic hydrazide, a unique growth regulant. Mimeo. Naugatuck Chemical Division, U. S. Rubber Company.

KUNKEL, L. O.

1943. Viruses in relation to the growth of plants. Torreya 43: 87-95.

Schoene, D. L., and O. L. Horrmann.

1949. Maleic hydrazide, a unique growth regulant. Science 109 : 588-590.

ZiMMERMAN, P. W.

1943. The formative influences and comparative effectiveness of various plant hormonelike compounds. Torreya $43:$ 98-115. 


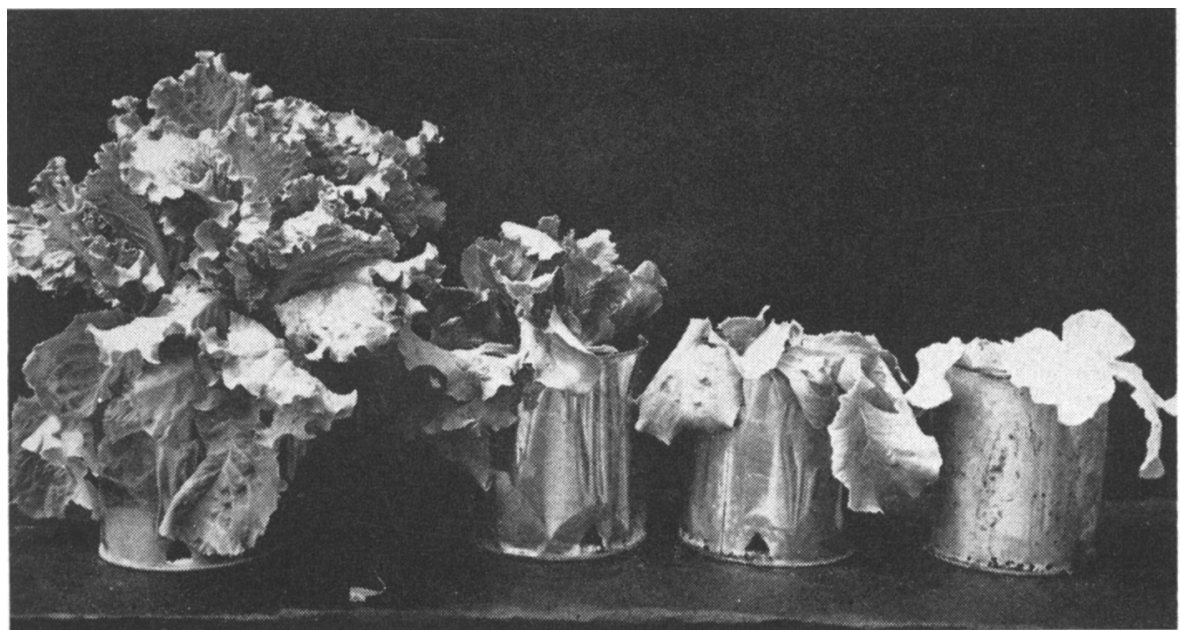

Fig. 12. Lettuce sprayed when 20 days old. Left to right: control, $0.1,0.2$, and 0.4 per cent maleic hydrazide; Vatsol, 0.024 per cent. Photographed 3 weeks after treatment.

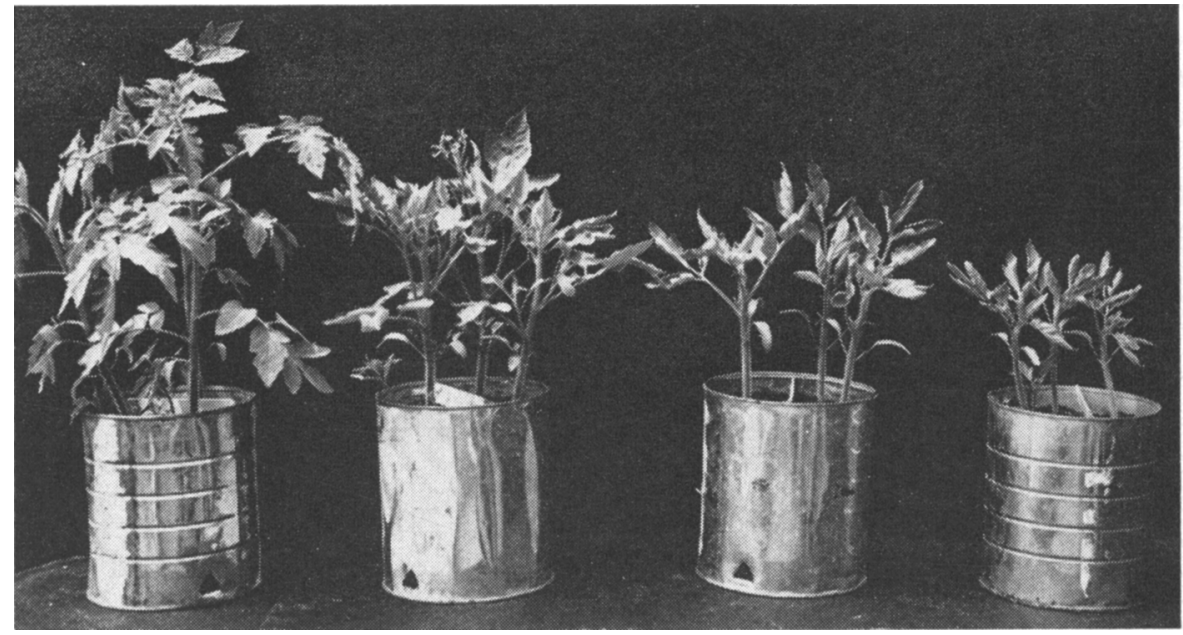

Fig. 13. Tomato sprayed when 20 days old. Left to right: control, $0.1,0.2$, and 0.4 per cent maleic hydrazide; Vatsol, 0.024 per cent. Photographed about 3 weeks after treatment. 


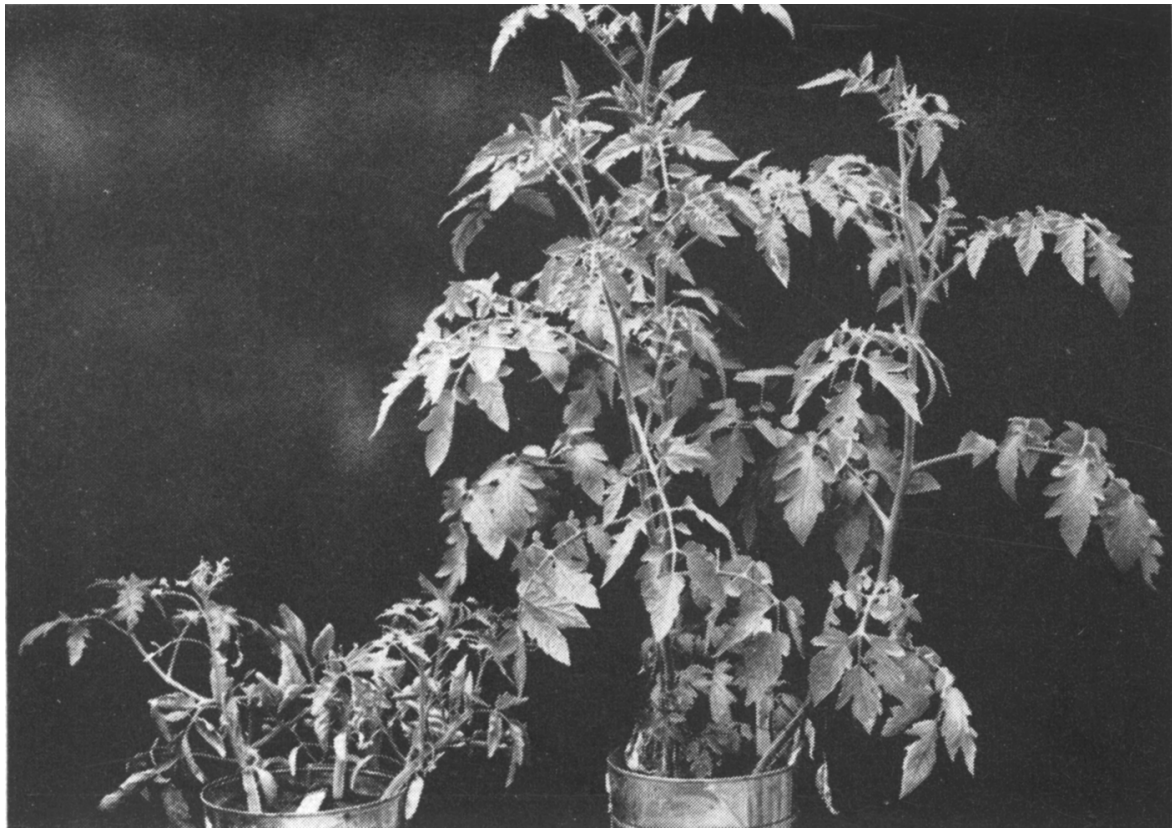

Fig. 14. Tomato sprayed with 0.4 per cent maleic hydrazide and 0.024 per cent Vatsol. Left: treated when 20 days old. Right: control. Photographed 42 days after treatment.

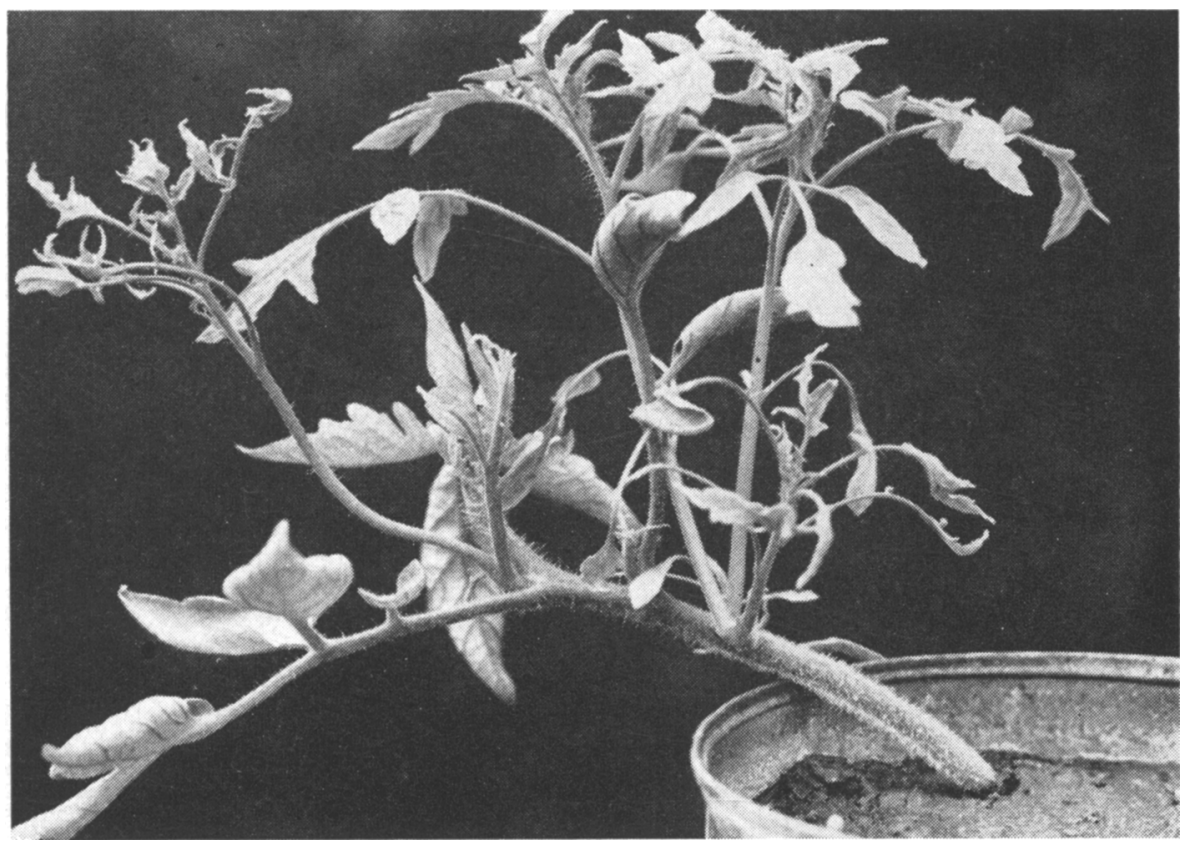

Fig. 15. Tomato sprayed with 0.4 per cent maleic hydrazide and 0.024 per cent Vatsol. After 42 days, plants showed symptoms typical of shoe-string virus. 


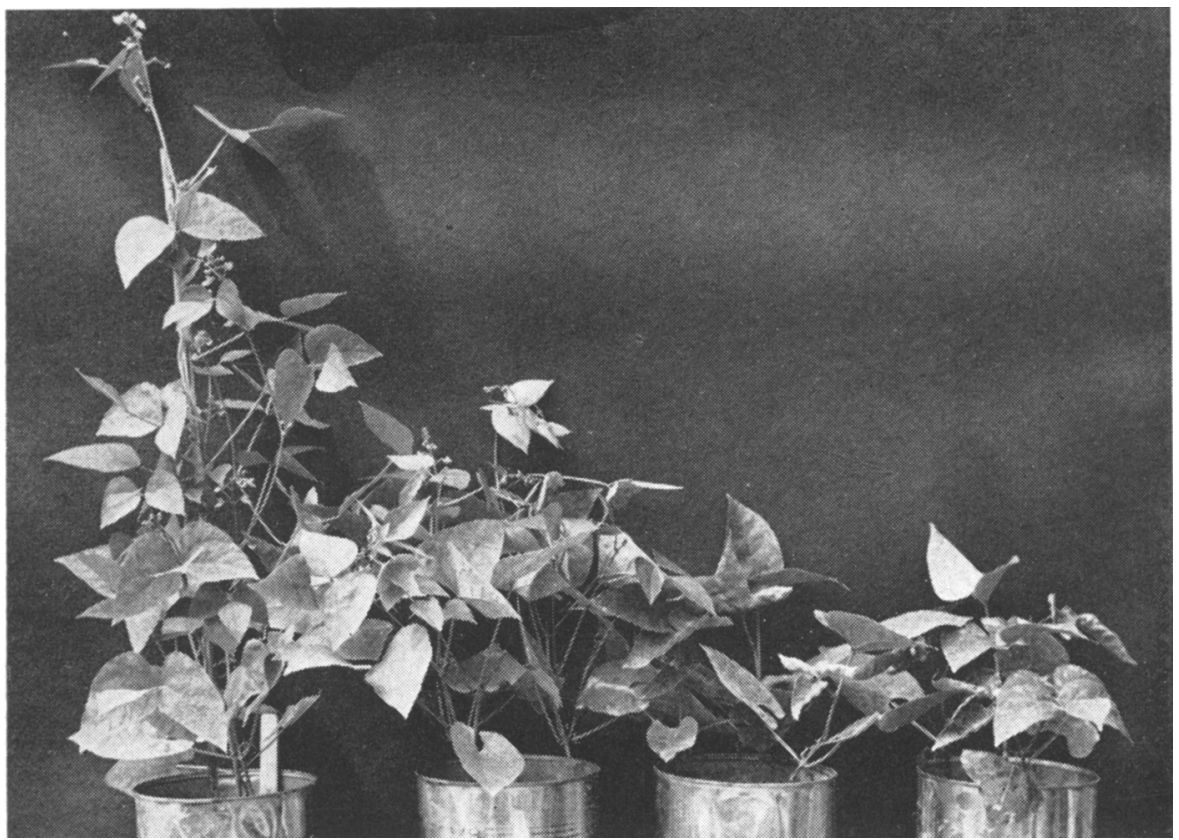

Fig. 16. Lima bean sprayed when 20 days old. Left to right: control, $0.1,0.2$, and 0.4 per cent maleic hydrazide; Vatsol, 0.024 per cent. Photographed 3 weeks after treatment.

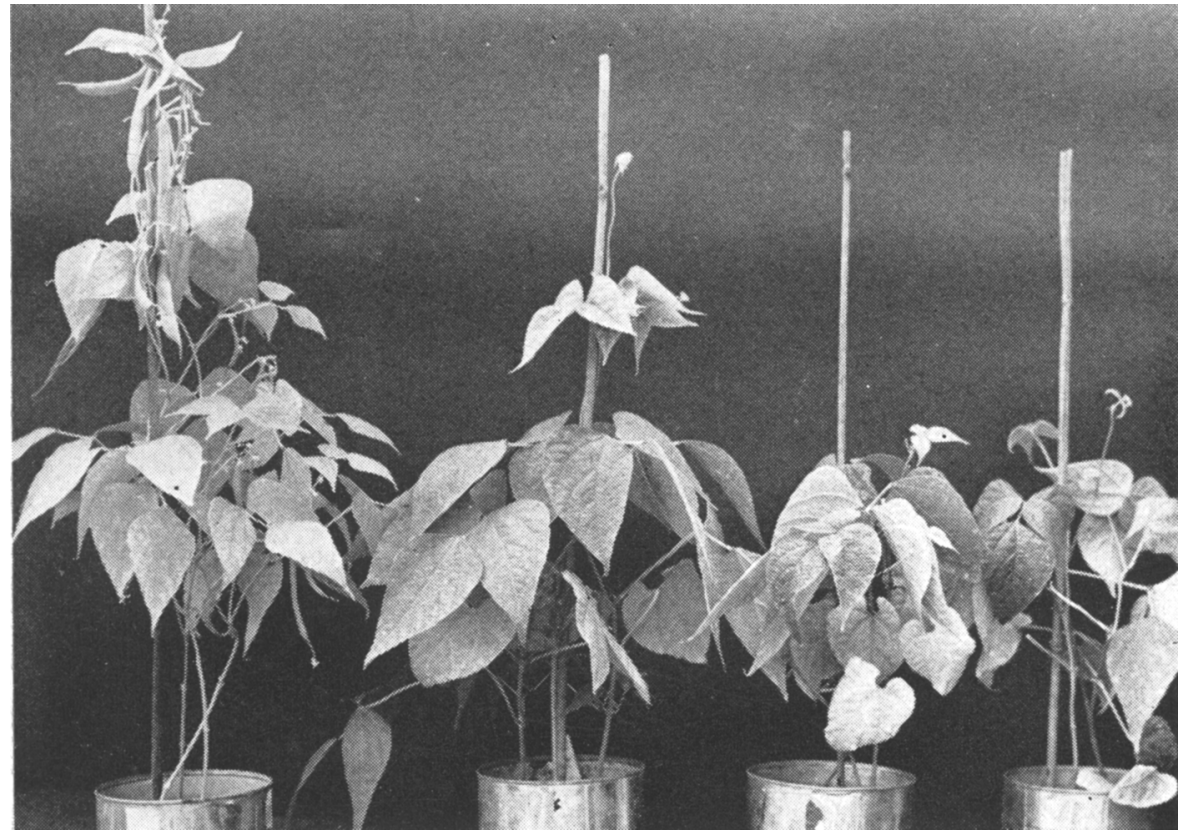

Fig. 17. Bountiful bean sprayed when 20 days old. Left to right: control, $0.1,0.2$, and 0.4 per cent maleic hydrazide; Vatsol, 0.024 per cent. Photographed 3 weeks after treatment. 


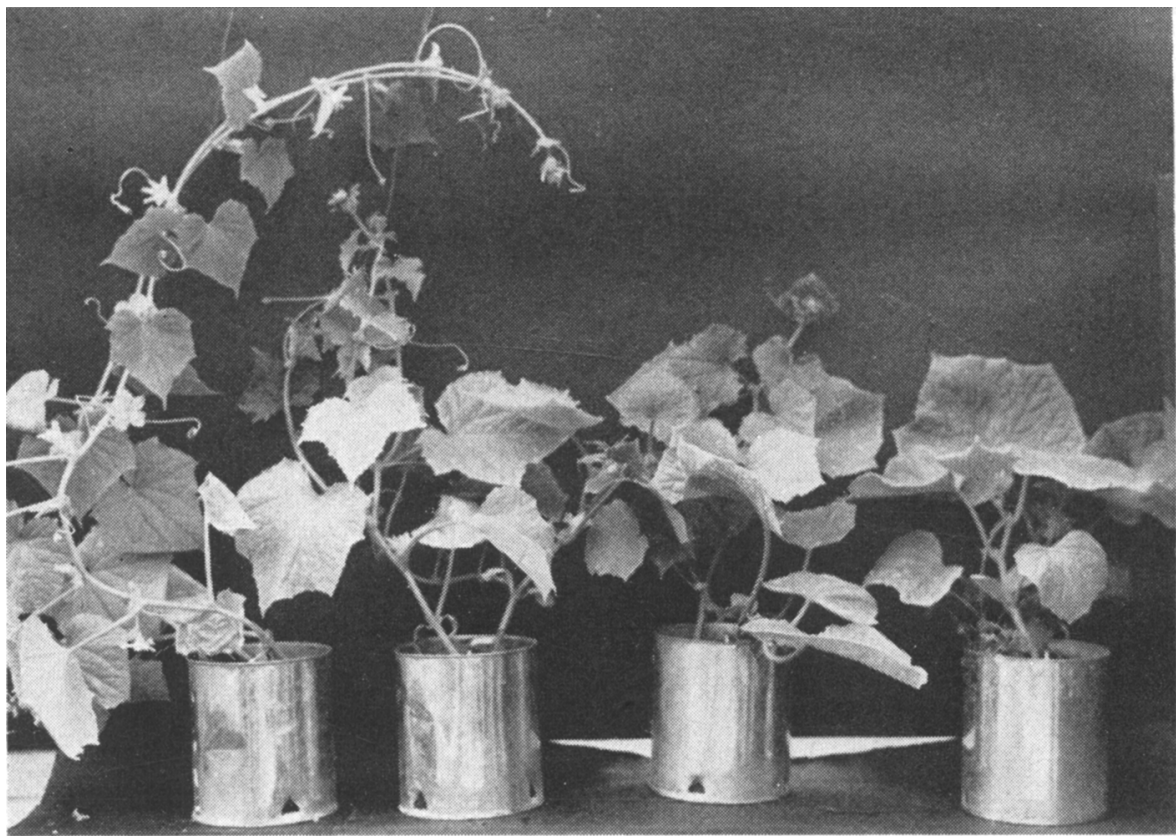

Fig. 18. Cucumber sprayed when 20 days old. Left to right: control, $0.1,0.2$, and 0.4 per cent maleic hydrazide; Vatsol, 0.024 per cent. Photographed 3 weeks after treatment.

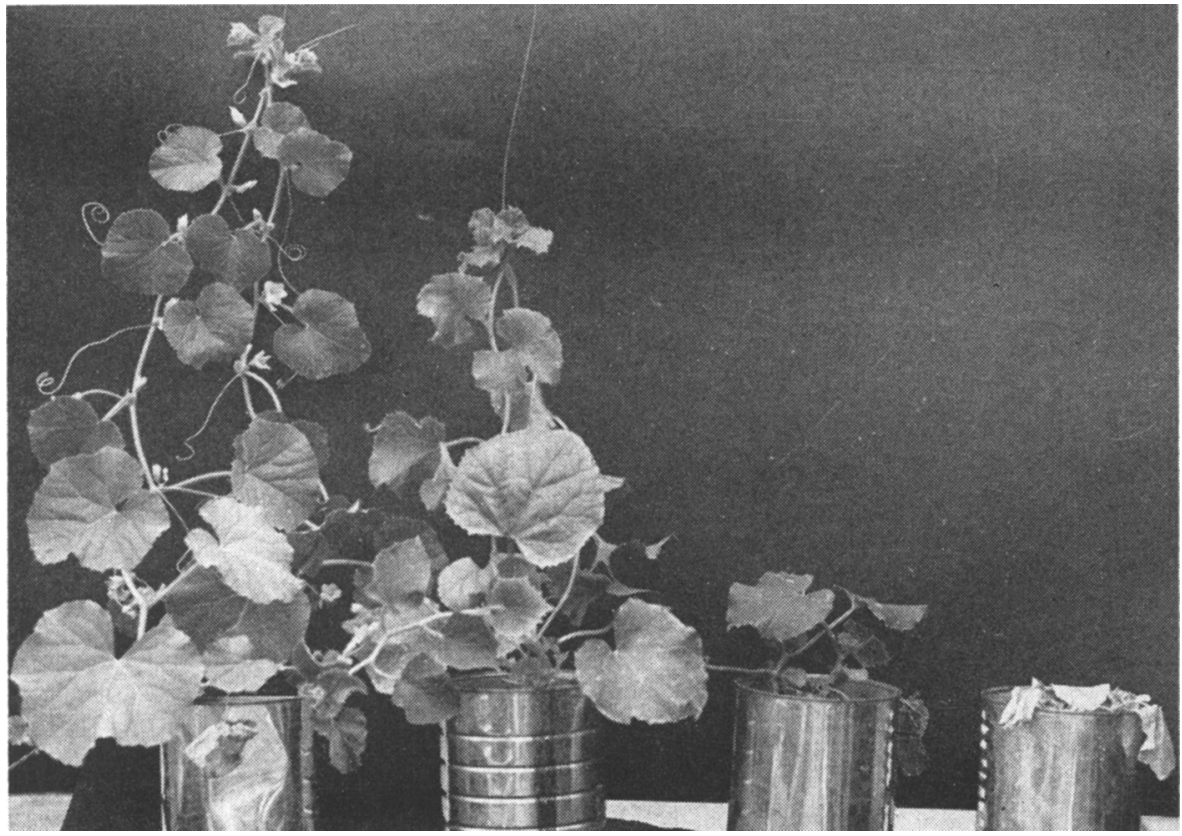

Fig. 19. Cantaloupe sprayed when 20 days old. Left to right: control, $0.1,0.2$, and 0.4 per cent maleic hydrazide; Vatsol, 0.024 per cent. Photographed 3 weeks after treatment. 


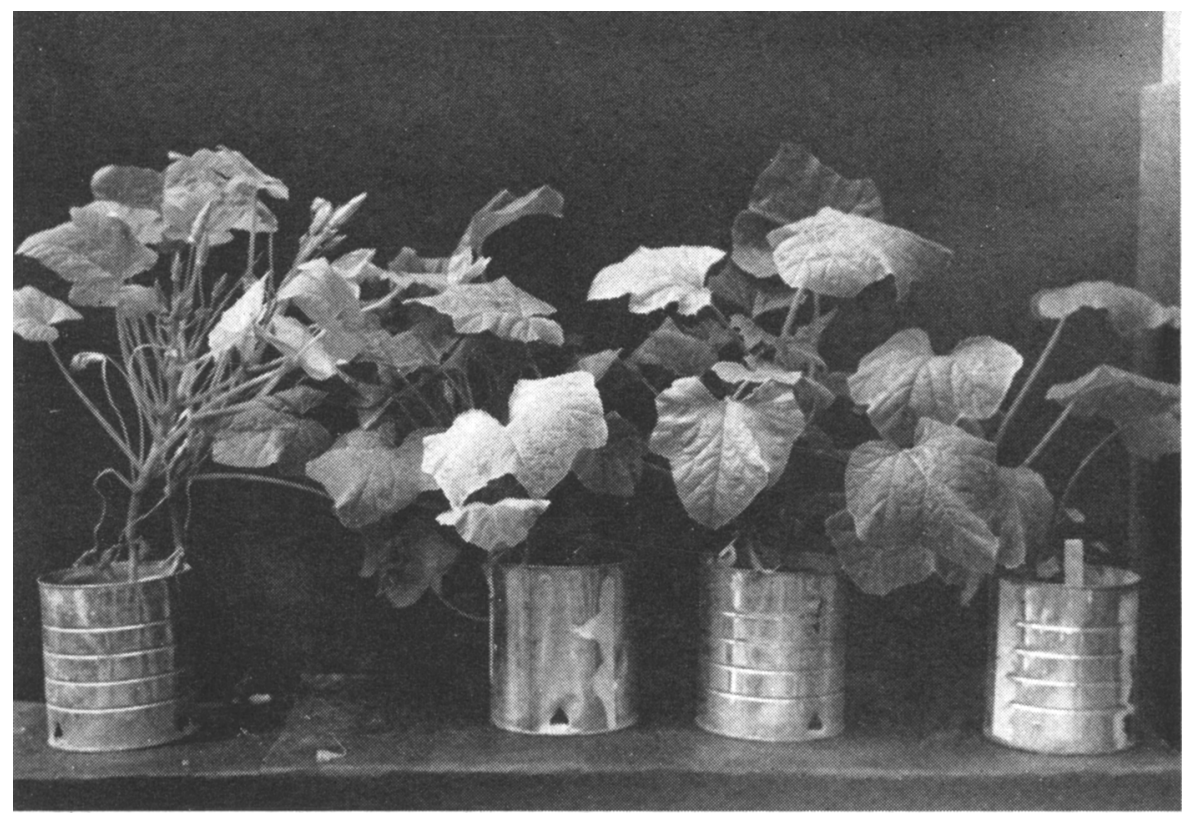

Fig. 20. Squash sprayed when 20 days old. Left to right: control, $0.1,0.2$, and 0.4 per cent maleic hydrazide; Vatsol, 0.024 per cent. Photographed 3 weeks after treatment.

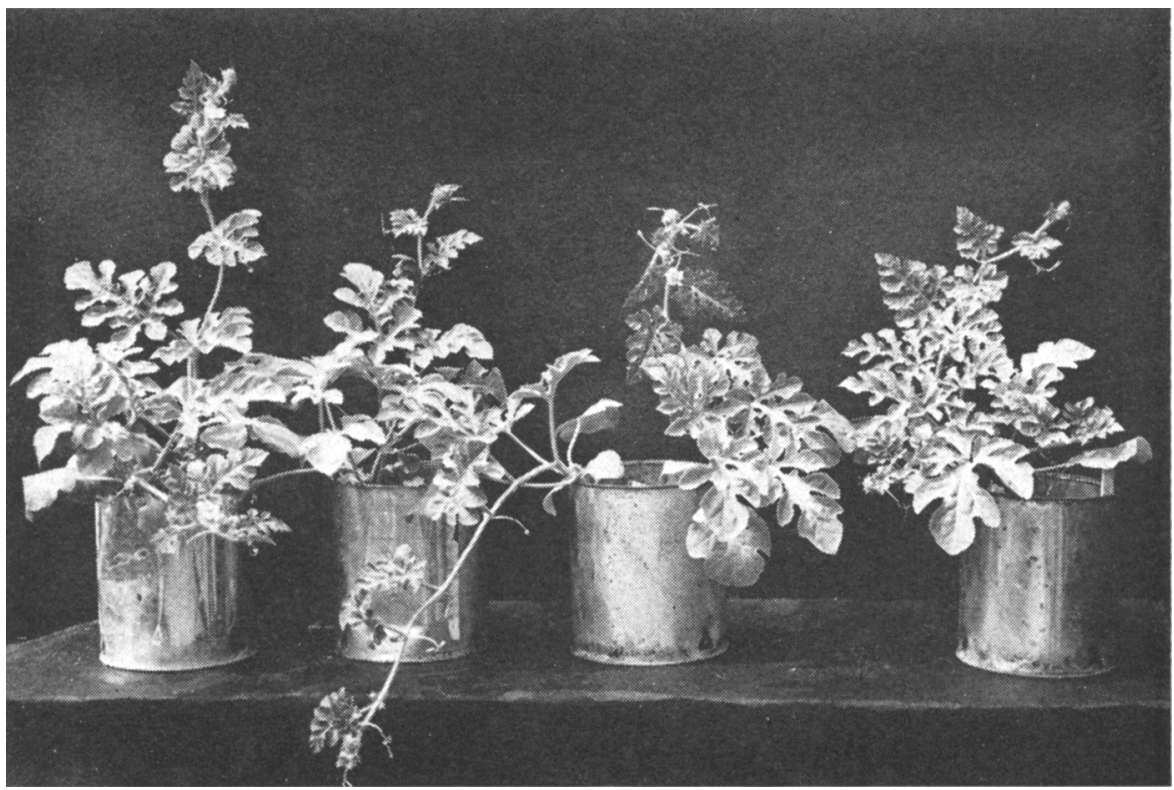

Fig. 21. Watermelon sprayed when 20 days old. Left to right: control, 0.1, 0.2, and 0.4 per cent maleic hydrazide; Vatsol, 0.024 per cent. Photographed 3 weeks after treatment. 


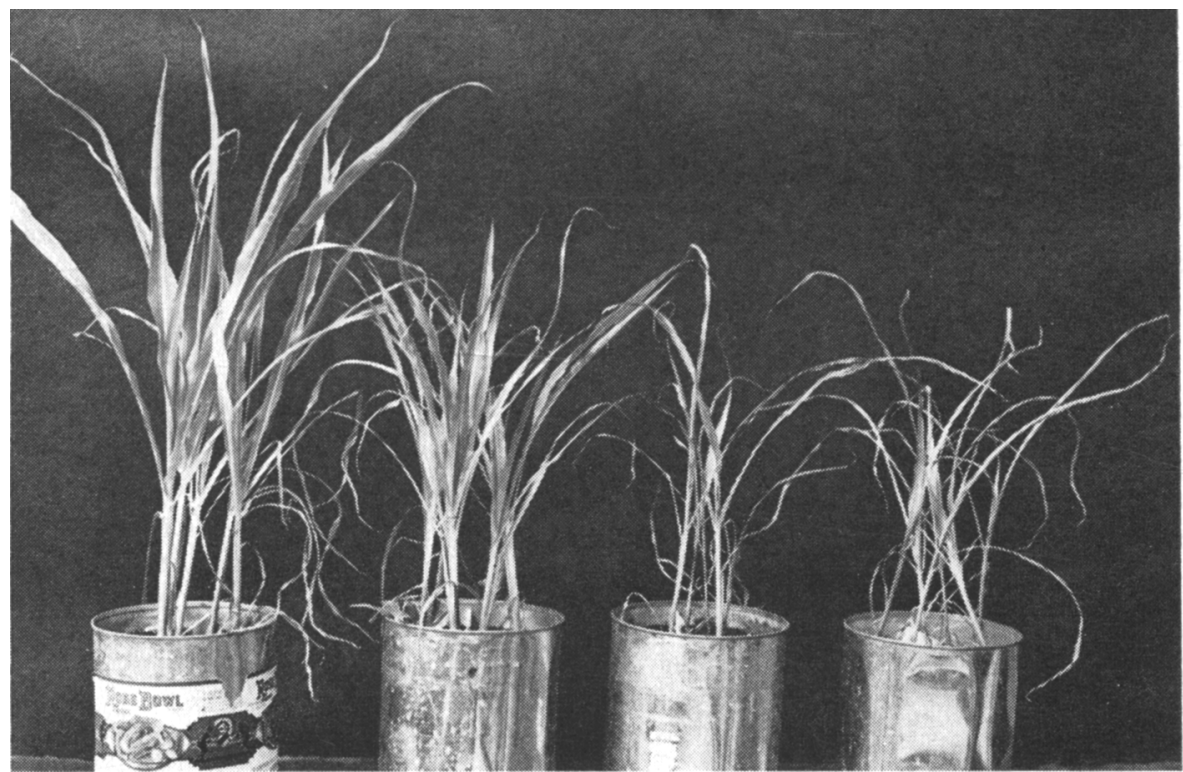

Fig. 22. Milo sprayed when 20 days old. Left to right: control, $0.1,0.2$, and 0.4 per cent maleic hydrazide; Vatsol, 0.024 per cent. Photographed 3 weeks after treatment.

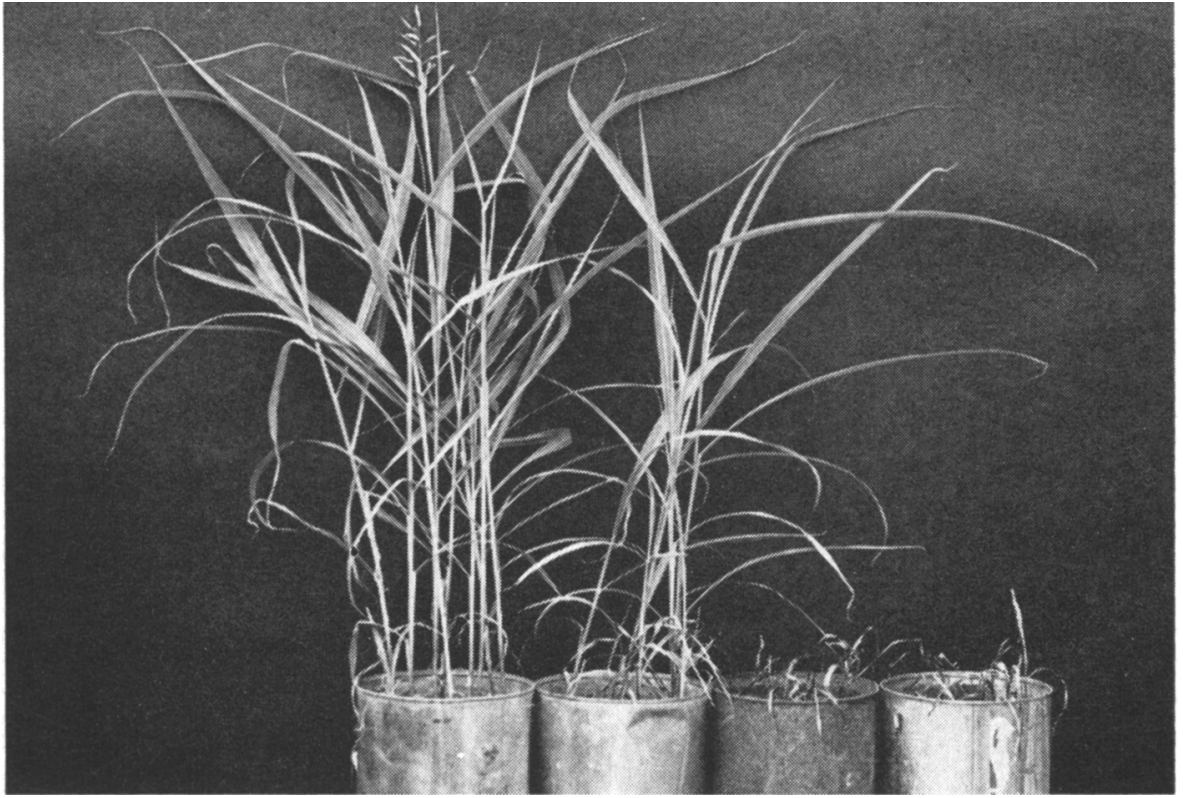

Fig. 23. Johnsongrass sprayed when 20 days old. Left to right: control, $0.1,0.2$, and 0.4 per cent maleic hydrazide; Vatsol, 0.024 per cent. Photographed 3 weeks after treatment. 


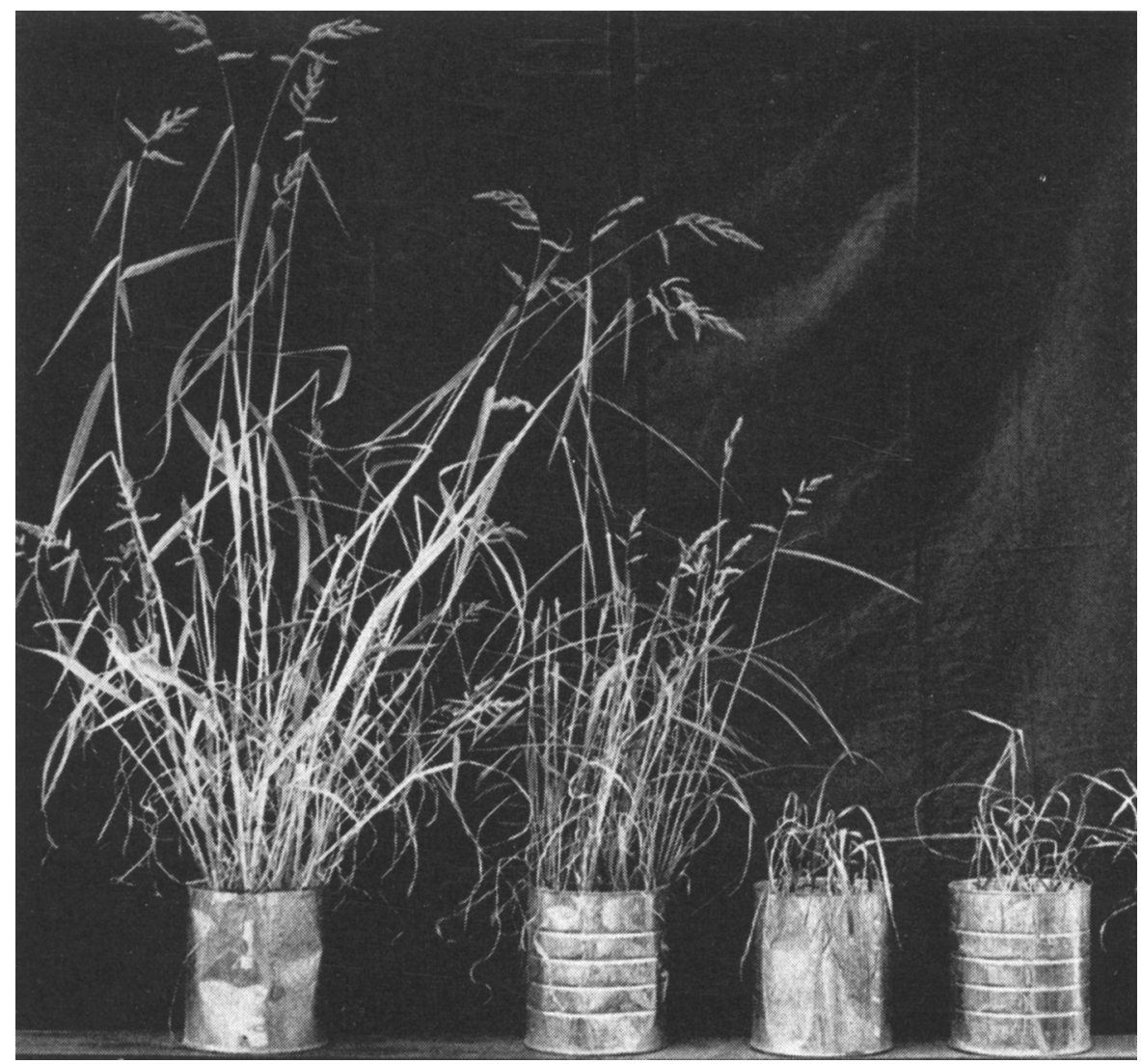

Fig. 24. Watergrass sprayed when 20 days old. Left to right: control, $0.1,0.2$, and 0.4 per cent maleic hydrazide; Vatsol, 0.024 per cent. Photographed 3 weeks after treatment. 


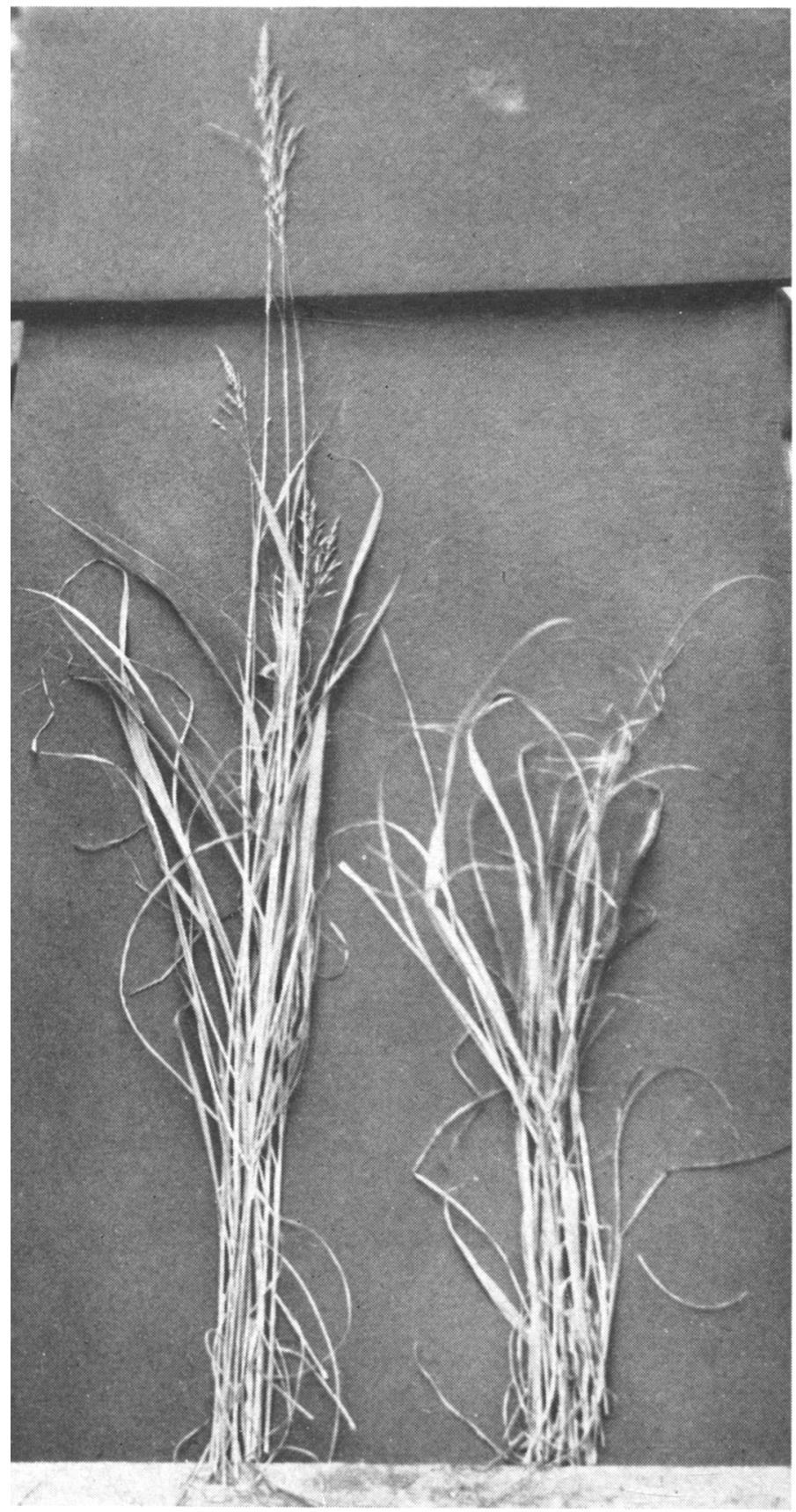

Fig. 25. Johnsongrass treated with maleic hydrazide. Left: control. Right: sprayed with 0.2 per cent maleic hydrazide and 0.024 per cent Vatsol. Harvested and photographed about 3 weeks after treatment. 
The journal Hilgardia is published at irregular intervals, in volumes of about 600 pages. The number of issues per volume varies.

Subscriptions are not sold. The periodical is sent as published only to libraries, or to institutions in foreign countries having publications to offer in exchange.

You may obtain a single copy of any issue free, as long as the supply lasts; please request by volume and issue number from:

\section{Publications Office \\ College of Agriculture \\ Berkeley 4, California}

The limit to nonresidents of California is 10 separate issues on a single order. A list of the issues still available will be sent on request.

In order that the information in our publications may be more intelligible it is sometimes necessary to use trade names of products or equipment rather than complicated descriptive or chemical identifications. In so doing it is unavoidable in some cases that similar products which are on the market under other trade names may not be cited. No endorsement of named products is intended nor is criticism implied of similar products which are not mentioned. 